\title{
PHYLOGENETIC RELATIONSHIPS OF Calomys sorellus COMPLEX (RODENTIA: CRICETIDAE), WITH THE DESCRIPTION OF TWO NEW SPECIES
}

\author{
Horacio Zeballos ${ }^{1}$, R. Eduardo Palma ${ }^{2}$, Pablo A. \\ Marquet $^{2,3}$, and Gerardo Ceballos ${ }^{4}$ \\ ${ }^{1}$ Instituto de Ciencias de la Naturaleza, Territorio y Energías Re- \\ novables, Pontificia Universidad Católica del Perú, Av. Universitaria \\ 1801, San Miguel, Lima 32, Perú \\ 2 Departamento de Ecología, Facultad de Ciencias Biológicas, \\ Pontificia Universidad Católica de Chile, Alameda 340, Santiago \\ 6513677, Chile \\ ${ }^{3}$ Instituto de Ecologia \& Biodiversidad (IEB), Casilla 653, Santiago, \\ Chile \\ ${ }^{4}$ Instituto de Ecología, Universidad Nacional Autónoma de México, \\ Apartado Postal 70-275, Mexico D.F. 04510, México \\ Autor de correspondencia: Horacio Zeballos; correo electrónico: \\ horaciozeballos@gmail.com
}

\begin{abstract}
We reviewed the phylogenetic relationships of forms assigned to Calomys sorellus based on the Cytochrome $b$ gene sequences and morphological comparisons. We present the first description of the evolutionary relationships within the $C$. sorellus species complex. The results show a clade with species from lowlands of Eastern of Andes and other clade with Andean species which contains: C. musculinus, C. sorellus and $C$. lepidus which would be species complex. One of the new species occurs in the Atiquipa Lomas in the coastal desert of southern Peru, and other on the occidental slope of southern Peru in Arequipa and Moquegua. These new species are based upon considering their phenotypic characteristics (size, coloration, pelage), geographic distribution, and molecular phylogeny.
\end{abstract}

Key words: New species, rodent, Sigmodontinae, biodiversity, Peru.

\section{RESUMEN}

Revisamos las relaciones filogenéticas de las formas asignadas a Calomys sorellus basados en secuencias nucleotídicas del gen mitocondrial Citocromo $b$ así como de caracteres morfológicos. Los resultados muestran un clado que agrupa a las formas de las tierras bajas al este de los Andes y a un clado andino, compuesto por: Calomys musculinus, Calomys sorellus y Calomys lepidus que serían complejos de especies. C. sorellus estaría compuesto por al menos cinco especies, tres de ellas previamente fueron definidas como subespecies, a las que agregamos dos especies nuevas. Una de ellas habita en las lomas de Atiquipa en la costa desértica del sur del Perú, y la otra en las vertientes occidentales de los Andes del sur del Perú en Arequipa y Moquegua. Estas nuevas especies están definidas por sus diferencias morfológicas y moleculares y por su tamaño corporal, pelaje y distribución geográfica.

Palabras clave: Especie nueva, roedor, Sigmodontinae, biodiversidad, Perú. 


\section{INTRODUCTION}

Sigmodontine rodents are one of the most diverse groups of mammals in the world inhabiting almost all terrestrial environments of South America (Catzeflis et al., 1992; Wilson and Reeder, 2005). The tribe Phyllotini, one of the most diverse groups in this subfamily, includes two very diverse genera, Phyllotis and Calomys. The genus Calomys inhabits a large region between Venezuela and Argentina in the Andean highlands and the eastern lowlands and is related to the oldest forms of the Sigmodontine radiation (Baskin, 1978). Most of these species inhabit the eastern lowlands of the Andes. Cabrera (1961) and Ellerman (1941) recognized 10 to 15 species in this genus, but the number was reduced to four by Hershkovitz (1962). However, two of these species Calomys laucha and Calomys callosus, have been considered a species' complex (Massoia et al., 1968; Pearson and Patton, 1976; Williams and Mares, 1978; Reig, 1986; Corti et al., 1987; Olds, 1988; Bonvicino and Almeida, 2000) and a recent revisions of the genus have recognized at least 13 species within it (Salazar-Bravo et al., 2001; Bonvicino et al., 2010; Musser and Carleton, 2005; Almeida et al., 2007; González-Ittig et al., 2007; Haag et al., 2007).

In the Peruvian Andes two species of Calomys have been recognized. Calomys lepidus occurs in the highlands of the Andes above $3,000 \mathrm{~m}$, from central Peru to northwestern Argentina (Pearson, 1951; Cabrera, 1961; Heshkovitz, 1962; Steppan, 1995). The second species, Calomys sorellus, is endemic to Peru, where it is widely distributed along the Andes from the northern most part of the country to the Peruvian Andes around Titicaca Lake (Pacheco, 2002). In the northern part of its range, C. sorellus lives above $2,000 \mathrm{~m}$ whereas in the Andean regions of southern Peru it occurs over 3,300 m (Cabrera, 1961; Heshkovitz, 1962; Pearson, 1951; Steppan, 1995), and its occurrence in western Bolivia is also very likely (Anderson, 1997). Three subspecies of $C$. sorellus have been recognized: C. s. sorellus, C. s. frida, and C.s. miurus.
Oliver Pearson (pers. comm.) captured one individual of the Calomys genus in the coastal region of Arequipa, without assigning it to any species. We collected additional specimens in the same locality. At first glance, those specimens did not appear to be similar to any species of the Calomys species already described. Therefore, to define the identity of those specimens we carried out analyses of phylogenetic relationships. So, in this paper we analyze molecular and morphological traits of the genus Calomys in Peru to evaluate its phylogenetic relationships and species composition.

\section{MATERIALS AND METHODS}

\section{Study area}

The Calomys specimens we used in this study included all its geographic range in Peru (Figure 1). The distribution range of $\mathrm{Ca}$ lomys in Peru extends along the Puna from the northern Andes to the southern international border with Bolivia and Chile. The genus is also known form a small area on the southern coast of the Arequipa department where the seasonal fog input supports the development of rich vegetation along hills know as "Loma formations" (Figure 1).

\section{Morphological characteristics}

We reviewed 240 Calomys specimens which are stored in the following collections: the Bolivian Collection of Fauna (CBF) in La Paz, Bolivia; the Museum of Natural History at the Universidad Nacional Mayor de San Marcos (MUSM) in Lima, Peru; and the Scientific Collection of Museum of Natural History of the Universidad Nacional de San Agustin (MUSA) in Arequipa, Peru (Appendix 1). We followed the terminology for cranial and dental morphology described by Hershkovitz (1962), Carleton and Musser (1989), Voss 1988, and Steppan (1995). External and cranial measurements (Tables 1,2 ) were recorded in millimeters $(\mathrm{mm})$ and weight in grams (g). Body measurements were obtained from the skin label; tail length was subtracted from total length to obtain the head-and-body 
Figure 1. MAP OF SPECIES DISTRIBUTION OF Calomys From Peru: C. sorellus (BLACK SQUARES); C. miurUS (WHITE CIRCLES); C. frida of Cusco (BLACK tRIANGLES); C. frida of PUNO (WHITE SQUARES); C. achaku (WHITE TRIANGLES, TYPE WHITE STAR); AND $\boldsymbol{C}$. chinchilico (BLACK STAR).

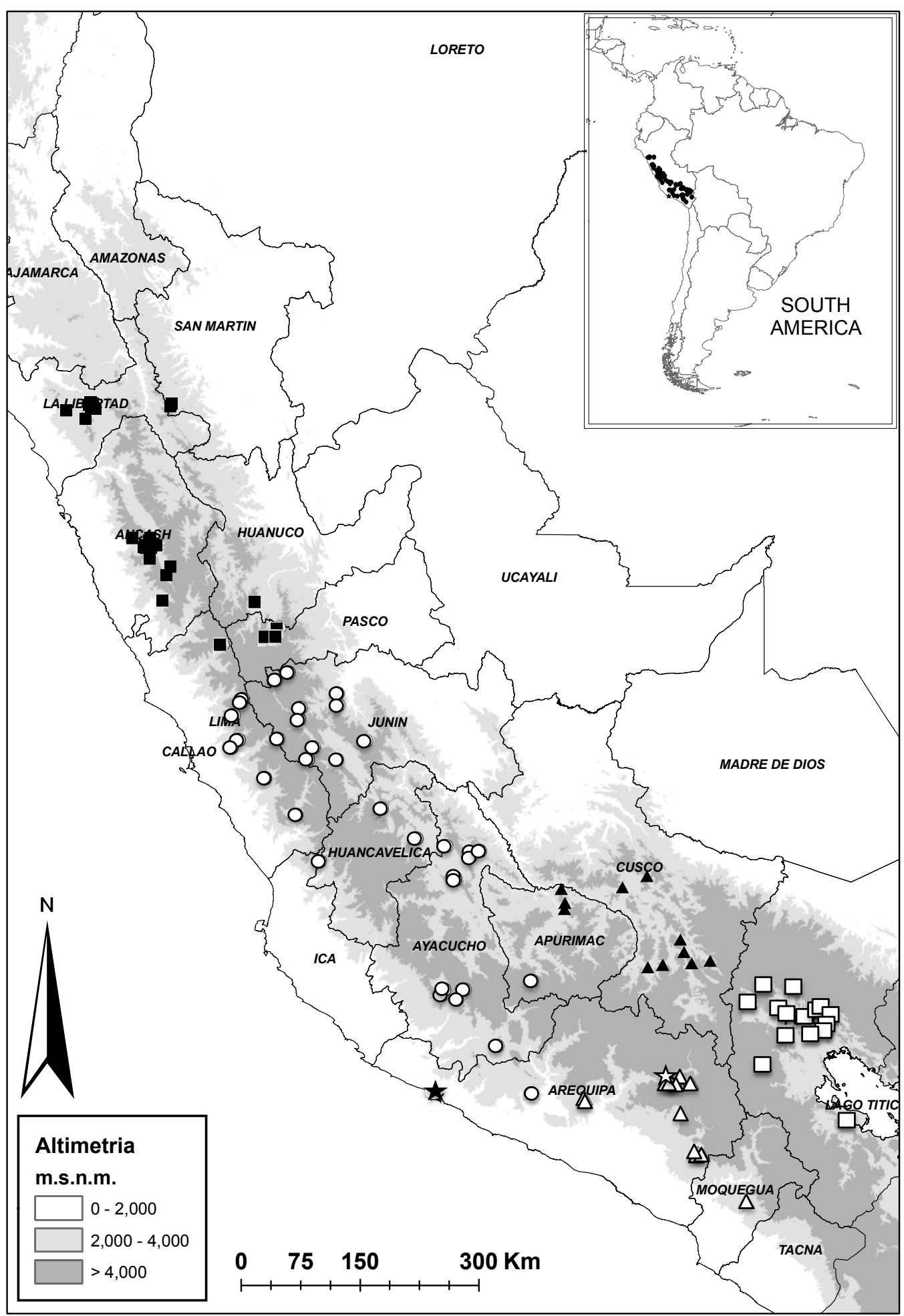


length (HB). Other measurements included: Total length (T); tail length (TL); hind foot length (HF); EL, ear length (EL); and weight (W). Cranial measurements corresponded to: CondyleIncisive Length; (CIL); LN, Nasallength (NL); Breadth of Braincase (BB); Breadth of Rostrum (BR); Zygomatic Breadth (ZB); Least Interorbital Breadth (LIB); LD, Length of Diastema (LD); Length of the Maxillary Molars (LM);Breadth of Bony Palate Across First Upper Molars (BP); Breadth of $\mathrm{Ml}$ (BM1); Breadth of the Incisor Tips (BIT); Height of Incisor (HI); Bullar length (BL);Bullar breadth (BW); Interbullar breadth (IBB); Interglenoid fossa breath (GB); and Mandible length (ML). We also assessed the cranial anatomy of specimens used during the study. We develop a comparative revision trait by trait between all species, choosing differential traits between them in order to obtain the diagnostic characters in every form. We followed Ridgway (1912) for color nomenclature.

\section{Molecular analyses}

We used the modified phenol-chloroform method (Longmire et al., 1988 and Laird et al., 1991) to extract DNA from tissues (liver or muscle) previously fixed with $96 \%$ ethanol. We amplified the Cytochrome $b$ gene of the mitochondrial genome (mtDNA) through the polymerase chain reaction (PCR; Saiki et al., 1988). Primers used were $\mathrm{H}-15767$ (Edwards et al., 1991) and L-14724 (Kocher et al., 1989). The thermal profile was $95{ }^{\circ} \mathrm{C}$ for 1.5 minutes for denaturation, $56{ }^{\circ} \mathrm{C}$ for 15 seconds for the annealing, and $72{ }^{\circ} \mathrm{C}$ for 1.5 minutes for extension; this process was repeated for 30 cycles. We included a sample of distilled water without DNA as a negative control in each reaction. We then used agarose gels coated with ethidium bromide to visualize the PCR products, and the successful reactions were purified using the QIAquick method (Qiagen, Valencia, California, USA). Sequencing reactions were performed using the same PCR primers labeled with the Big Dye Terminator Cycle Sequencing Ready Reaction kit (from Applied Biosystems, Foster City, California, USA.). DNA sequences were analyzed with the automatic sequencer $A B I$
Prism 310 (Applied Biosystems) at the laboratory of Molecular Diversity, Pontificia Universidad Católica de Chile. Sequences were aligned using the Clustal $\mathrm{X} 1.83$ program (Thompson et al., 1997), checked visually, and edited with the programs BioEdit 7.0 (Hall 1999) and DnaSP 4.1 (Rozas et al., 2003).

\section{Phylogenetic analyses}

We chose the evolution model that best fit the data using the Akaike Information Criterion (AIC; Akaike, 1974) implemented in the program ModelTest (Posada and Crandall, 1998). The best model of evolution was GTR + $\mathrm{I}+\mathrm{G}(-\mathrm{InL}=8538.9287, \mathrm{AIC}=17097.8574)$ with a proportion of invariable sites of 0.3052 and a 0.9353 gamma distribution. Base frequencies were: $A=0.29980, C=0.28740, G=0.12070$ and $T=0.29210$; and the substitution rates $A C=1.3623, A G=4.6718, A T=1.5242, C G$ $=0.4259, \mathrm{CT}=7.8241$ and $\mathrm{GT}=1.0000 \mathrm{We}$ estimated the index of substitution saturation (Iss) with the program DAMBE 4.2.13 (Xia et al., 2003), and our calculated value of Iss $=0.3494$ was significantly less than the Iss (0.4782), suggesting little saturation and that the data matrix can be used in phylogenetic reconstructions. Thephylogenetic reconstruction was performed using the Maximum Likelihood approach (ML) implemented in PAUP 4.0 (Swofford, 2002). We also conducted a Bayesian analysis implemented in MrBayes 3.1 (Huelsenbeck and Ronquist, 2001, Ronquist and Huelsenbeck, 2005). To measure the confidence of the trees generated with ML, a bootstrap was used (ML) (Felsenstein, 1981; 1985). To build consensus trees and to estimate the probability values of its nodes (By), the Bayesian analyses estimated three million generations; this number did not include the first generations, which represented $25 \%$ of the total. In addition, to infer the phylogeny we performed Maximum Parsimony and distance analyses (Minimum Evolution) implemented in PAUP 4.0 (Swofford, 2002). To root the trees we use the out group criterion, including four species of phyllotines: Eligmodontia puerulus, Andalgalomys pearsonomys, Auliscomys 
sublimis and Loxodontomys micropus. The rate of nucleotide evolution was estimated using the Kimura 2 parameter model, (K2P Kimura, 1980) implemented in the program MEGA5 (Tamura et al., 2011). The phylogenetic analyses involved 26 nucleotide sequences of the genus Calomys. Since that all analyzed lowland species are recognized as full species (except "innominate") (Salazar-Bravo et al., 2001; Bonvicino et al., 2003, 2010; Musser and Carleton, 2005; Almeida et al., 2007; GonzálezIttig et al., 2007; Haag et al., 2007) we use our values of genetic distance and long branch to define the specific separation in the Andean species.

\section{RESULTS}

\section{Phylogenetic relationships of An- dean Calomys}

Species in the C. sorellus complex showed a high degree of morphological simi- larity. However, external and cranial measurements showed some significant differences when compared with t-student test (Tables 1, 2). The genus Calomys consists of two sister clades; the "Lowlands clade", that includes the species in the eastern Andean lowlands and a Venezuelan species, and the "Andean clade" that includes forms of the Andes from Peru and Bolivia to northern Chile and northwestern Argentina (Figure 2).

Our analyses revealed that the Andean clade included $C$. sorellus and $C$. lepidus which are monophyletic complexes of species. $C$. sorellus consists of five full species: $C$. sorellus, C. frida, and C. miurus and two undescribed species of Arequipa and Moquegua. The other group contains forms currently assigned to Calomys sorellus, which our results also indicate that constitutes a species complex (Figure 1). In fact, the molecular and morphological analyses suggest that the sorellus group consists of at least five distinct species between the two

Table 1. Number of specimens, average, standard deviation, and range of external measurements of Calomys species from Central Andes, with special reference to Peruvian forms. These measurements include Total length (T); Tail length (TL); Head and body (HB); Hind foot (HF); Ear length (EL); Weight (W). Single asterick (*) indicates Cusco and Abancay forms and a double asterisk $\left.{ }^{* *}\right)$ indicates Arequipa and southwestern Puno forms.

\begin{tabular}{|c|c|c|c|c|c|c|}
\hline & $\mathrm{T}$ & TL & $\mathrm{HB}$ & $\mathrm{HF}$ & EL & W \\
\hline \multicolumn{7}{|c|}{ sorellus } \\
\hline (24) & $\begin{array}{l}140.00 \pm 14.06 \\
116-156(18)\end{array}$ & $\begin{array}{l}55.70 \pm 8.67 \\
43-67(18)\end{array}$ & $\begin{array}{l}84.30 \pm 6.63 \\
70-89(17)\end{array}$ & $\begin{array}{l}19.50 \pm 2.16 \\
18-23(17)\end{array}$ & $\begin{array}{l}16.90 \pm 2.16 \\
16-19(17)\end{array}$ & $\begin{array}{l}17.30 \pm 1.51 \\
14.5-19(14)\end{array}$ \\
\hline \multicolumn{7}{|c|}{ frida Cusco } \\
\hline (12) & $\begin{array}{l}168.33 \pm 7.34 \\
155-174(10)\end{array}$ & $\begin{array}{l}80.86 \pm 6.47 \\
69-90(11)\end{array}$ & $\begin{array}{l}85.14 \pm 5.93 \\
76-92(11)\end{array}$ & $\begin{array}{l}22.19 \pm 3.04 \\
20.5-29(10)\end{array}$ & $\begin{array}{l}18.43 \pm 0.53 \\
18-19(11)\end{array}$ & $\begin{array}{l}18.75 \pm 5.44 \\
13-26(7) \\
\end{array}$ \\
\hline \multicolumn{7}{|c|}{ frida Puno } \\
\hline (6) & $\begin{array}{l}152.50 \pm 25.63 \\
103-174(6)\end{array}$ & $\begin{array}{l}73.40 \pm 3.78 \\
71-80(5)\end{array}$ & $\begin{array}{l}91.33 \pm 10.01 \\
80-103(6)\end{array}$ & $\begin{array}{l}17.93 \pm 1.43 \\
15.29-19.1(6)\end{array}$ & $\begin{array}{l}17.57 \pm 1.42 \\
14.9-18.8\end{array}$ & $\begin{array}{l}22 \pm 6.08 \\
15-26(3)\end{array}$ \\
\hline \multicolumn{7}{|c|}{ achaku } \\
\hline (24) & $\begin{array}{l}151.35 \pm 13.62 \\
129-178(20)\end{array}$ & $\begin{array}{l}70.76 \pm 5.88 \\
59-80(20)\end{array}$ & $\begin{array}{l}80.40 \pm 10.03 \\
65-99(22)\end{array}$ & $\begin{array}{l}18.09 \pm 1.42 \\
14.6-20(22)\end{array}$ & $\begin{array}{l}16.45 \pm 1.79 \\
14.14-21.02 \\
(22)\end{array}$ & $\begin{array}{l}17.92 \pm 6.53 \\
7-28(12)\end{array}$ \\
\hline \multicolumn{7}{|c|}{ miurus } \\
\hline (80) & $\begin{array}{l}149.48 \pm 9.75 \\
118-171(71)\end{array}$ & $\begin{array}{l}65.81 \pm 7.59 \\
42-80(71)\end{array}$ & $\begin{array}{l}83.66 \pm 6.72 \\
69-98(71)\end{array}$ & $\begin{array}{l}18.78 \pm 1.48 \\
11-22(73)\end{array}$ & $\begin{array}{l}17.43 \pm 1.62 \\
13-21.3(74)\end{array}$ & $\begin{array}{l}16.56 \pm 3.59 \\
11.1-28(62)\end{array}$ \\
\hline \multicolumn{7}{|c|}{ chinchilico } \\
\hline (22) & $\begin{array}{l}144.53 \pm 10.45 \\
128-161(21)\end{array}$ & $\begin{array}{l}66.82 \pm 4.76 \\
60-75(21)\end{array}$ & $\begin{array}{l}77.89 \pm 8.31 \\
61.9-89(21)\end{array}$ & $\begin{array}{l}18.33 \pm 0.93 \\
16.5-19.6(21)\end{array}$ & $\begin{array}{l}16.76 \pm 1.22 \\
14-19.6(21)\end{array}$ & $\begin{array}{l}14.61 \pm 2.81 \\
11-19(9)\end{array}$ \\
\hline
\end{tabular}




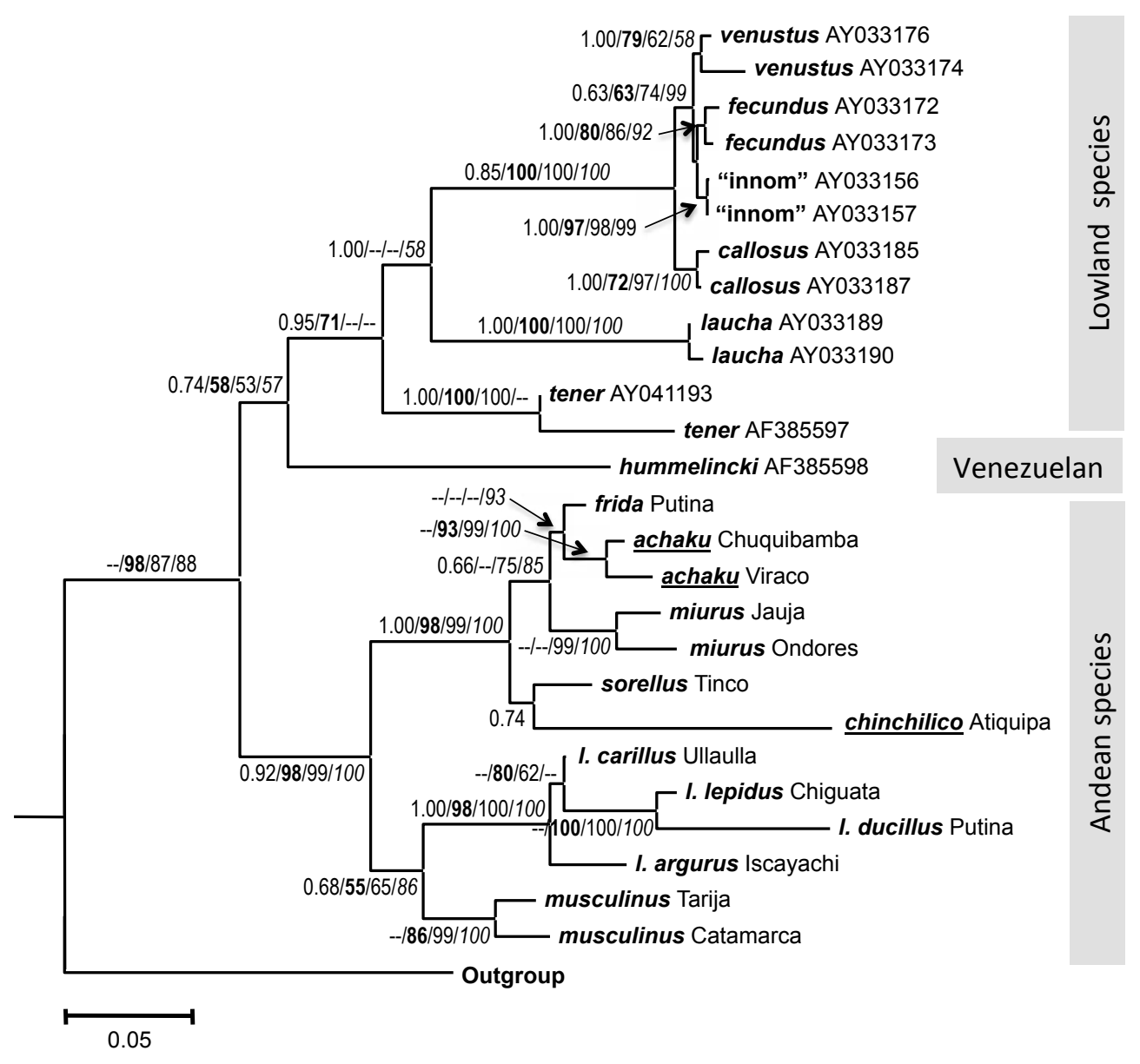

Figure 2. Tree of PHyLOGENETIC RELATIONSHIPS OF THE GEnUs Calomys Genus in the Central Andes OBTAINED THROUGH BAYESIAN INFERENCE, MAXIMUMLIKELIHOOD, MAXIMUM Parsimony and Minimum EVOLUTION ANALYSES BASED ON CYTOCHROME $b$ MITOCHONDRIAL GENE SEQUENCES. FIRST NUMBERS INDICATE POSTERIOR PROBABILITY, AND BOOTSTRAP VALUES FOR MAXIMUM LIKELIHOOD (BOLd), Maximum ParsiMONy (THIRD) AND MINIMUM EVOLUTION (ITALIC). ONLY BOOTSTRAP VALUES ABOVE $50 \%$ ARE SHOWN. NEW SPECIES UNDERLINED.

strongly supported clades (By: 1.00, ML: 98). One consists of $C$. sorellus from northern Peru and an undescribed species of Atiquipa (New species 1), located in the "Lomas" formations in the coastal desert of southern Peru (ML: 69, B: 0.99). Both species are separated by about $600 \mathrm{~km}$ (Figure 1). The other subclade includes C. miurus of west central Peru and C. frida group (By: 0.66) in Puno, Cusco and Arequipa departments (Figures 1,2); the Arequipa and Moquegua form (southwestern of Peru) is an undescribed species (New species 2, Figures $1,2)$.

The Calomys lepidus is formed by two sister groups strongly sustained (By: 0.92, ML: 98), namely Calomys lepidus and Calomys musculinus. The Calomys lepidus group is a species complex. Our results showed that $C$.
I. argurus from southern Bolivia and northern Argentina is separated from forms of $C$. lepidus from Peru and Bolivia (By: 1.00, ML: 98). Additionally, our analyses indicated that C. I. lepidus and C. I. ducilla are also strongly differentiated (ML: 100) with a remarkably long branch.

Interestingly, the branch length of the closely related species of the Andes is larger than those of the lowlands. We also found that $\mathrm{K} 2 \mathrm{P}$ distance values between Cytochrome $b$ sequences within the same species were below $0.99 \%$ with the exception of $C$. tener and $C$. venustus (Table 5). The same distance values between species were greater than $1.85 \%$; the Andean specific forms exhibited higher values than lowland species (Table 5). 
Table 2. Number of specimens and average and standard deviation (in parenthesis) of cranial measurements of Calomys species from the Central Andes, with special reference to Peruvian forms. Single asterisk (*) indicates Cusco and Abancay forms and a double asterisk (**) Puno.

\begin{tabular}{|c|c|c|c|c|c|c|}
\hline & chinchilico & frida* & frida $* *$ & achaku & miurus & sorellus \\
\hline & $(22)$ & (12) & (7) & (19) & (80) & (24) \\
\hline \multirow[t]{2}{*}{ CIL } & 20.50 & 21.39 & 21.66 & 20.75 & 21.17 & 21.76 \\
\hline & $(0.78)$ & $(0.82)$ & (1.36) & $(0.35)$ & $(0.73)$ & $(1.12)$ \\
\hline \multirow[t]{2}{*}{ LN } & 9.03 & 9.52 & 8.87 & 9.20 & 9.45 & 9.56 \\
\hline & $(0.49)$ & $(0.69)$ & $(0.93)$ & $(0.80)$ & $(0.48)$ & $(0.63)$ \\
\hline \multirow[t]{2}{*}{ BB } & 10.60 & 11.13 & 10.99 & 9.20 & 10.92 & 11.06 \\
\hline & $(0.44)$ & $(0.33)$ & $(0.58)$ & $(0.80)$ & $(0.29)$ & (0.39) \\
\hline \multirow[t]{2}{*}{$B R$} & 4.07 & 4.29 & 4.02 & 4.07 & 4.28 & 4.365 \\
\hline & $(0.18)$ & $(0.32)$ & $(0.46)$ & $(0.37)$ & $(0.24)$ & $(0.24)$ \\
\hline \multirow[t]{2}{*}{ ZB } & 11.80 & 12.50 & 12.22 & 12.29 & 12.22 & 12.63 \\
\hline & $(0.47)$ & $(0.66)$ & $(0.93)$ & $(0.66)$ & $(0.44)$ & $(0.56)$ \\
\hline \multirow[t]{2}{*}{ LIB } & 3.67 & 3.99 & 3.84 & 3.65 & 3.91 & 3.92 \\
\hline & $(0.11)$ & $(0.13)$ & $(0.22)$ & $(0.16)$ & $(0.16)$ & $(0.28)$ \\
\hline \multirow[t]{2}{*}{ LD } & 5.50 & 5.82 & 5.46 & 5.49 & 5.68 & 5.89 \\
\hline & $(0.26)$ & $(0.43)$ & $(0.7)$ & $(0.49)$ & $(0.27)$ & $(0.41)$ \\
\hline \multirow[t]{2}{*}{ LM } & 3.49 & 3.74 & 3.68 & 3.45 & 3.62 & 3.68 \\
\hline & $(0.09)$ & $(0.09)$ & $(0.26)$ & $(0.12)$ & $(0.13)$ & $(0.26)$ \\
\hline \multirow[t]{2}{*}{ BP } & 4.84 & 4.96 & 4.93 & 4.85 & 4.96 & 5.14 \\
\hline & $(0.17)$ & $(0.19)$ & $(0.35)$ & $(0.27)$ & $(0.19)$ & $(0.19)$ \\
\hline \multirow[t]{2}{*}{ BM1 } & 1.16 & 1.22 & 1.2 & 1.16 & 1.18 & 1.17 \\
\hline & $(0.06)$ & $(0.08)$ & $(0.07)$ & $(0.10)$ & $(0.06)$ & $(0.09)$ \\
\hline \multirow[t]{2}{*}{ BIT } & 1.25 & 1.37 & 1.25 & 1.31 & 1.32 & 1.29 \\
\hline & $(0.09)$ & $(0.07)$ & $(0.11)$ & $(0.16)$ & $(0.08)$ & $(0.12)$ \\
\hline \multirow[t]{2}{*}{$\mathrm{HI}$} & 3.33 & 3.58 & 3.62 & 3.55 & 3.573 & 3.69 \\
\hline & $(0.28)$ & $(0.33)$ & $(0.27)$ & $(0.31)$ & $(0.27)$ & $(0.26)$ \\
\hline \multirow[t]{2}{*}{$B L$} & 3.71 & 3.86 & 3.75 & 3.84 & 3.60 & 3.73 \\
\hline & $(0.17)$ & $(0.24)$ & $(0.45)$ & $(0.17)$ & $(0.26)$ & $(0.39)$ \\
\hline \multirow[t]{2}{*}{ BW } & 3.05 & 3.03 & 3.15 & 2.99 & 3.06 & 3.19 \\
\hline & $(0.14)$ & $(0.25)$ & $(0.24)$ & $(0.23)$ & $(0.19)$ & $(0.26)$ \\
\hline \multirow[t]{2}{*}{ IBB } & 2.43 & 2.56 & 2.61 & 2.42 & 2.55 & 2.44 \\
\hline & $(0.27)$ & $(0.32)$ & $(0.18)$ & $(0.26)$ & $(0.23)$ & $(0.26)$ \\
\hline \multirow[t]{2}{*}{ GB } & 9.89 & 10.30 & 10.37 & 10.05 & 10.20 & 10.41 \\
\hline & $(0.38)$ & $(0.48)$ & $(0.51)$ & $(0.37)$ & $(0.34)$ & $(0.37)$ \\
\hline \multirow[t]{2}{*}{$M L$} & 14.01 & 14.79 & 14.16 & 13.87 & 14.42 & 14.88 \\
\hline & $(0.66)$ & $(0.72)$ & $(1.06)$ & $(1.02)$ & $(0.54)$ & $(0.72)$ \\
\hline
\end{tabular}




\section{Morphological comparisons}

Species in the $C$. sorellus complex showed a high degree of morphological similarity. However, external and cranial measurements (Tables 1, 2) showed some significant differences when compared with t-student test. The undescribed form from Lomas of Atiquipa is the sister species of the nominal form, C. sorellus (Figure 2), both differ from each in body size, skull size, hind feet, and morphologic cranial structures and coloration (Figure 3; Tables $3,4)$. They showed subtle differences with $C$. miurus, differing in color, size of hind feet, skull size, and cranial structures (Table 4). The other undescribed form of the southwestern Andes of Peru (Figures 1,2), differed from all other species by its pale coloration and morphology (Table 1, 2, 3 and 4). Finally, the phylogenetic analysis showed that this form is closely related to $C$. frida and $C$. miurus (Figure 2). The undescribed form from Lomas of Atiquipa also differs markedly from nominal $C$. frida from Cusco and Apurimac in all measurements, but with similar weight and cranial structures, coloration, and external morphology (Tables 3, 4).

The morphological differences in external and cranial features, molecular phylogeny, and differential measurements across the C. sorellus complex support our proposition of species level differentiation for five taxa (Calomys sorellus, Calomys frida, Calomys miurus and two new species). The description of these differences is also presented in the description of the new species.

\section{Forms of the Calomys sorellus complex}

Calomys frida, Thomas 1917

Hesperomys frida Thomas 1917

Hesperomys frida frida Gylden stolpe 1932

Calomys frida Frida Cabrera 1961

Calomys sorellus Pacheco et al. 2009

Type locality-Chospyoc, Cusco, Peru.

Distribution-Calomys frida is distributed in the Andean valleys of Cusco and Apurimac Departments above $2800 \mathrm{~m}$ and in the Department of Puno above 3500 masl (Figure 1).

Diagnosis-We retain in $C$. frida the forms of C. sorellus complex from Puno because we lack molecular sequences for differentiation; however both exhibit differential morphology that may suggest a specific separation (Figure 3 ). Calomys frida have two morphological forms, one inhabiting the Cusco and Apurimac Department sand the other inhabiting Puno. The nominal form (Cusco) has a long tail in relation to HB $(92.27 \%$ versus $83.19 \%)$; the foramen

Table 3. Comparison of external measurements and length of the skull (CIL) of Calomys chinchilico with other forms of Calomys sorellus group. With the test. The values that differ significantly in bold.

\begin{tabular}{|l|l|l|l|l|l|l|l|}
\hline A & $\mathrm{T}$ & $\mathrm{TL}$ & $\mathrm{HB}$ & $\mathrm{HF}$ & $\mathrm{EL}$ & $\mathrm{W}$ & $\mathrm{CIL}$ \\
\hline $\begin{array}{l}\text { chinchilico-frida } \\
\text { Cusco }\end{array}$ & 0,0001 & 0,0237 & 0,2438 & 0,0001 & 0,0001 & 0,0843 & 0,0081 \\
\hline $\begin{array}{l}\text { chinchilico-frida } \\
\text { Puno }\end{array}$ & 0,2167 & 0,0078 & 0,0025 & 0,4037 & 0,0621 & 0,0136 & 0,0213 \\
\hline chinchilico-achaku & 0,0519 & 0,0262 & 0,2131 & 0,4890 & 0,8940 & 0,1731 & 0,5488 \\
\hline chinchilico-miurus & 0,5430 & 0,5162 & 0,1358 & 0,0492 & 0,3808 & 0,1507 & 0,0011 \\
\hline chinchilico-sorellus & 0,4783 & 0,7289 & 0,0170 & 0,0134 & 0,0719 & 0,0144 & 0,0004 \\
\hline achaku-frida Cusco & 0,0353 & 0,0128 & 0,0256 & 0,0002 & 0,0026 & 0,9766 & 0,2328 \\
\hline achaku-frida Puno & 0,8846 & 0,3367 & 0,0256 & 0,8136 & 0,1391 & 0,3457 & 0,2525 \\
\hline achaku-miurus & 0,3343 & 0,1607 & 0,5851 & 0,0185 & 0,2858 & 0,5664 & 0,3099 \\
\hline achaku-sorellus & 0,2856 & 0,0021 & 0,2207 & 0,0000 & 0,1221 & 0,7975 & 0,0341 \\
\hline
\end{tabular}




\begin{tabular}{|c|c|c|c|c|c|}
\hline 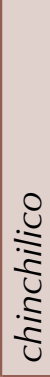 & 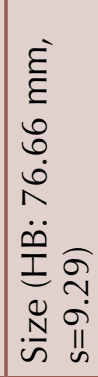 & 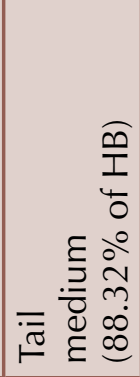 & 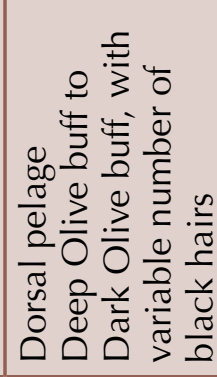 & 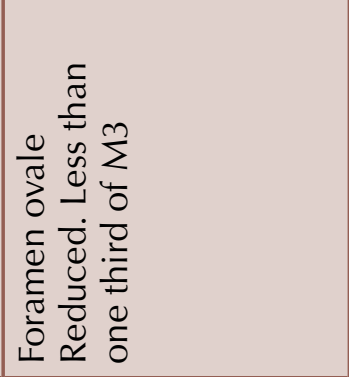 & 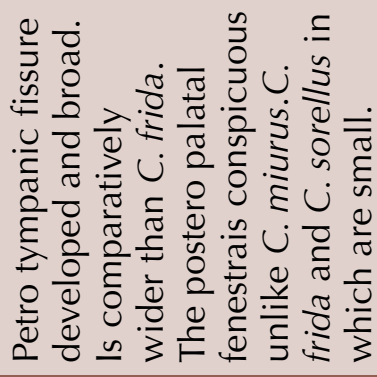 \\
\hline 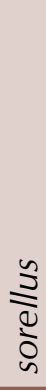 & 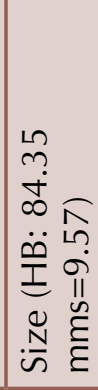 & 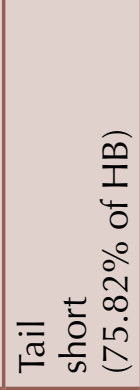 & 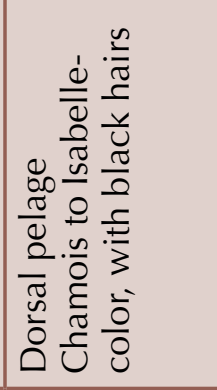 & 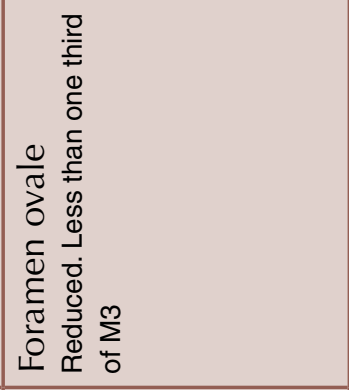 & 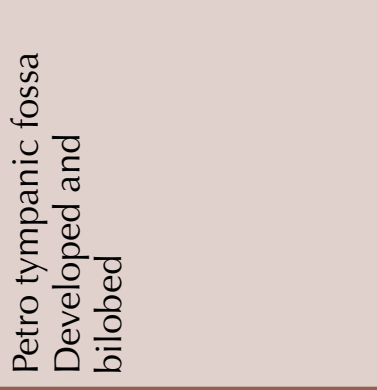 \\
\hline : & 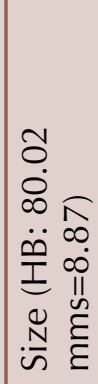 & 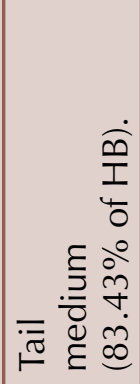 & 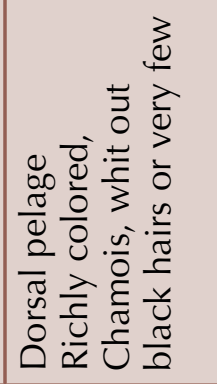 & 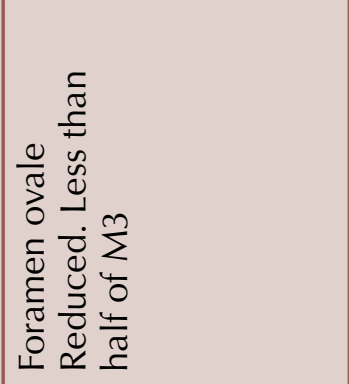 & 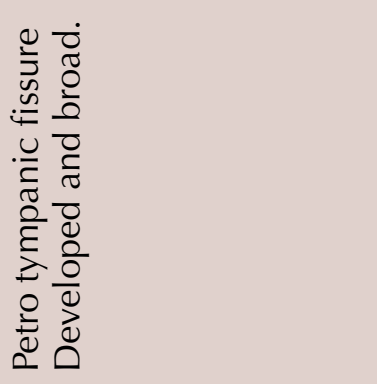 \\
\hline$\frac{\vec{z}}{\frac{\pi}{\tilde{d}}}$ & 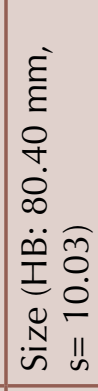 & 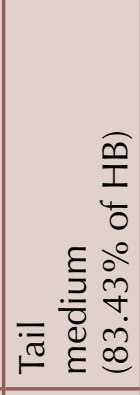 & 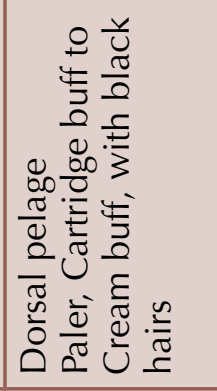 & 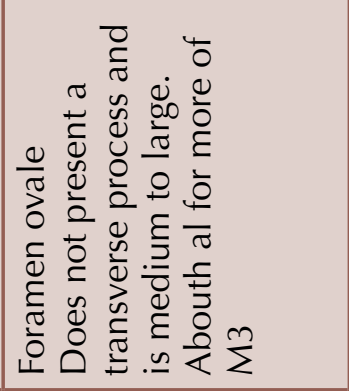 & 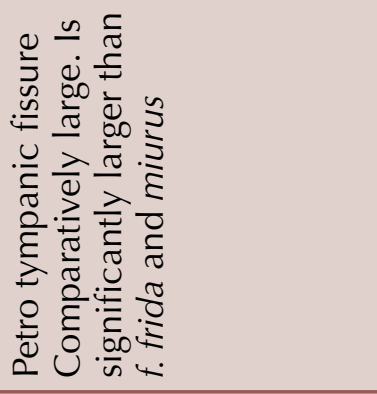 \\
\hline 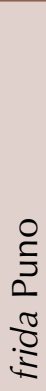 & 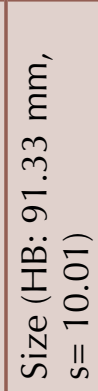 & 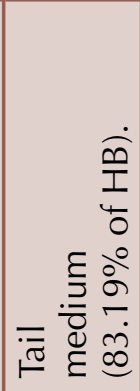 & 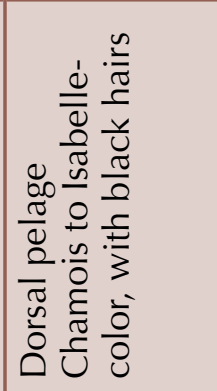 & 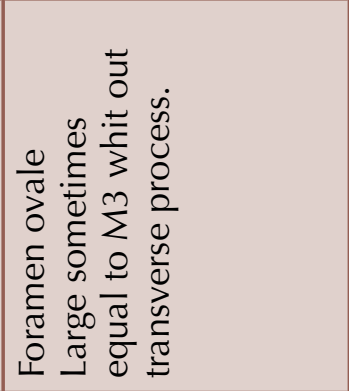 & 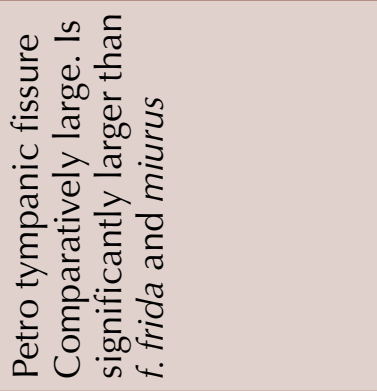 \\
\hline 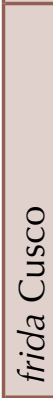 & 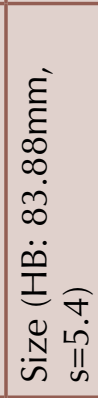 & 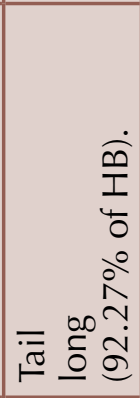 & 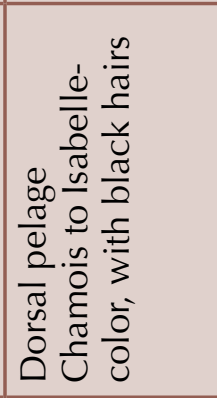 & 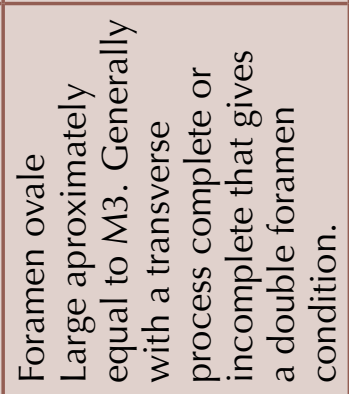 & 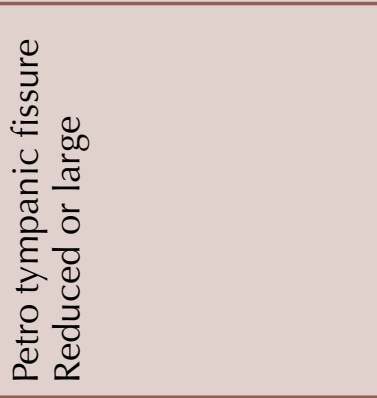 \\
\hline
\end{tabular}




\begin{tabular}{|c|c|c|c|c|c|}
\hline 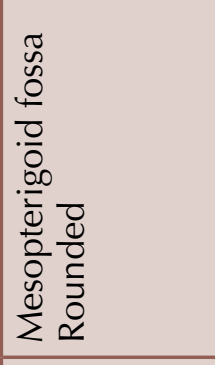 & 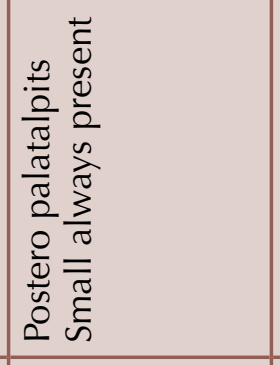 & 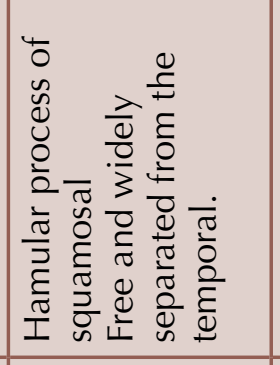 & 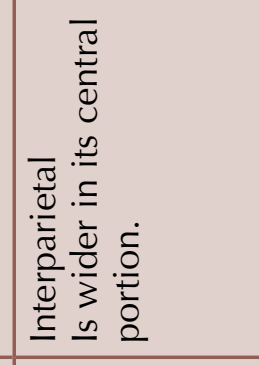 & 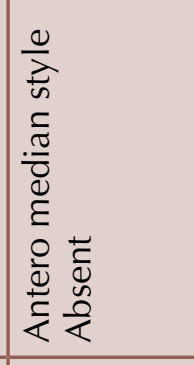 & 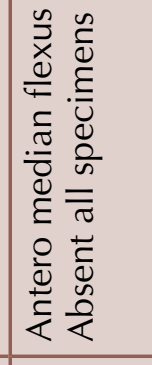 \\
\hline 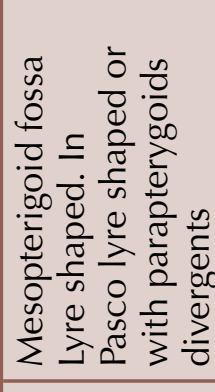 & 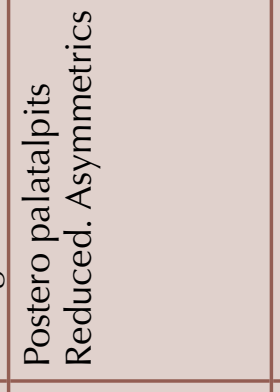 & 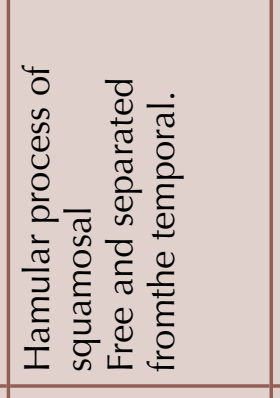 & 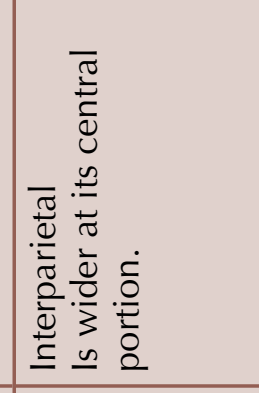 & 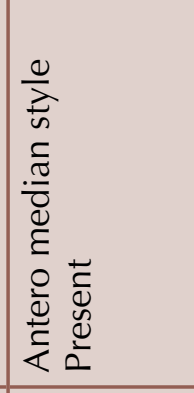 & 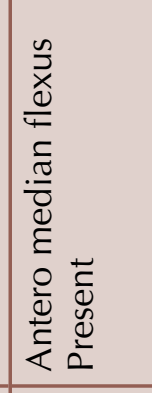 \\
\hline 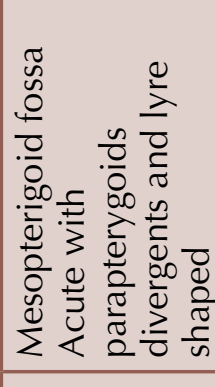 & 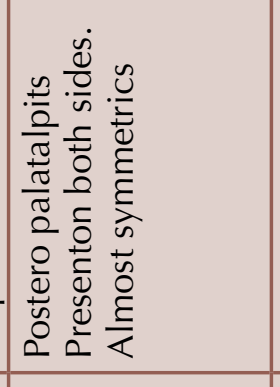 & 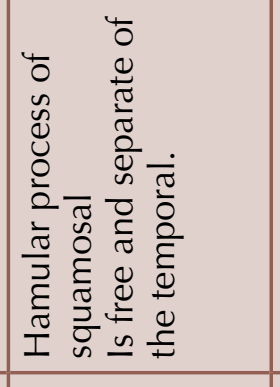 & 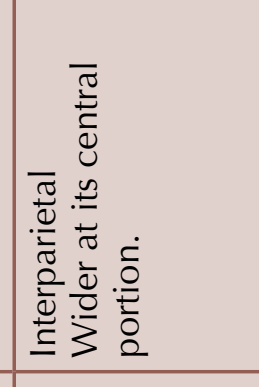 & 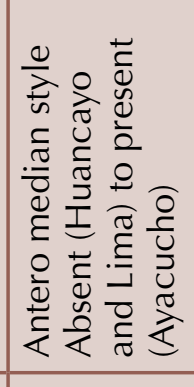 & 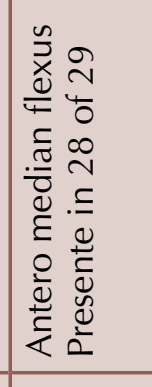 \\
\hline 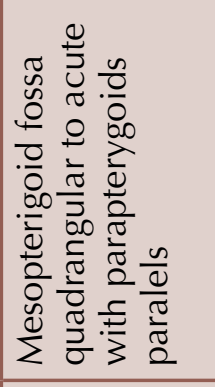 & 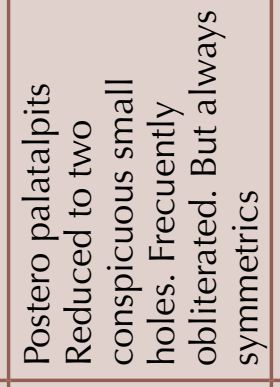 & 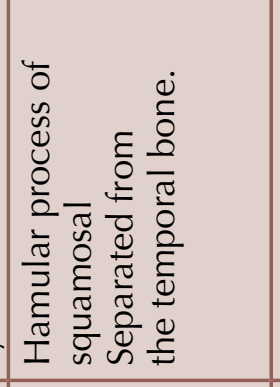 & 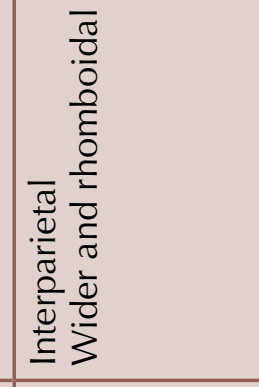 & 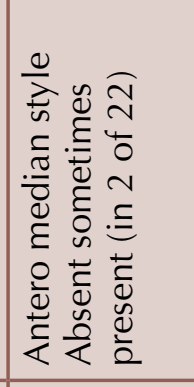 & 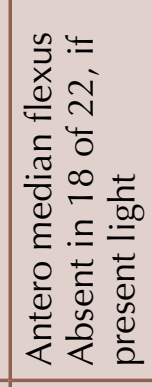 \\
\hline 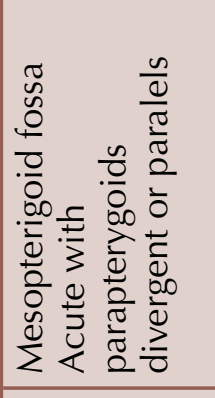 & 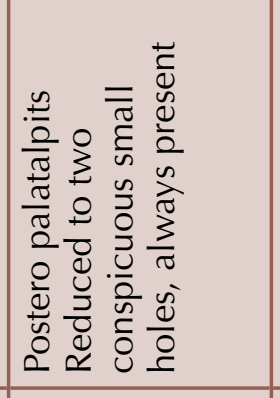 & 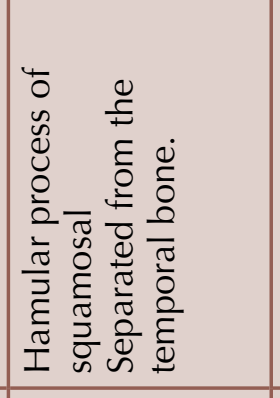 & 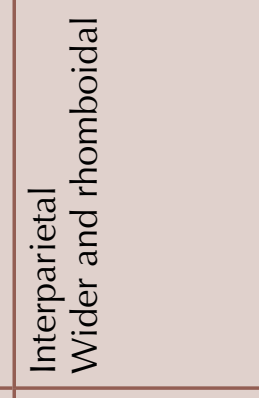 & 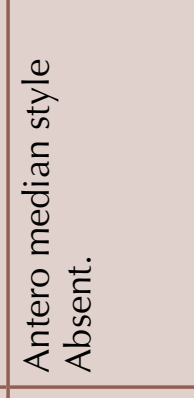 & 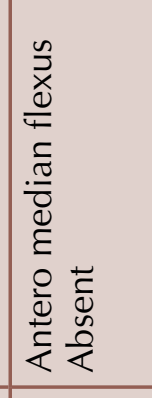 \\
\hline 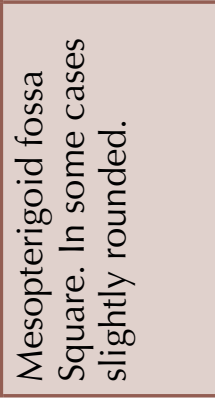 & 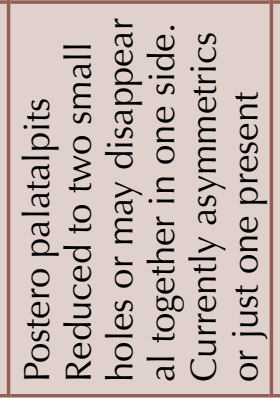 & 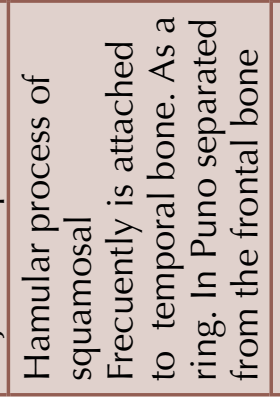 & 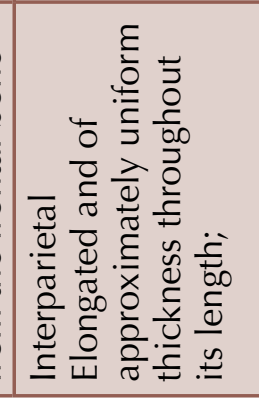 & 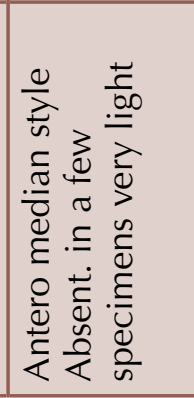 & 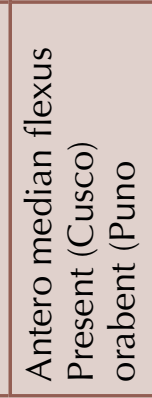 \\
\hline
\end{tabular}




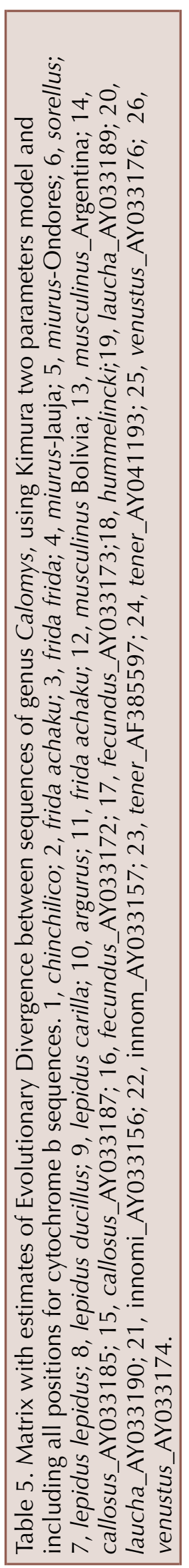

น

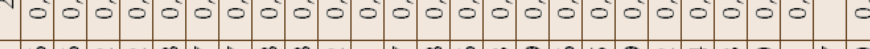

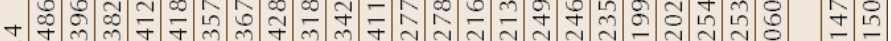
ป

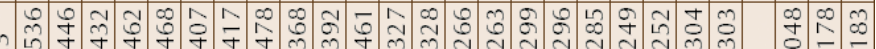
^

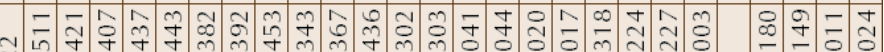

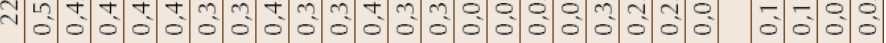

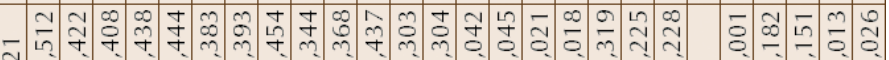
1 o c.

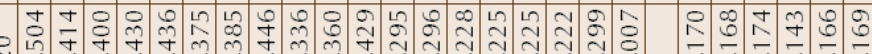

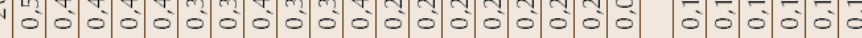

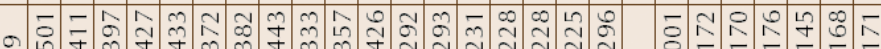

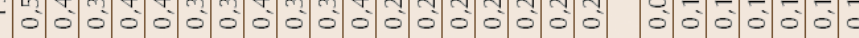
$\infty$ 芋

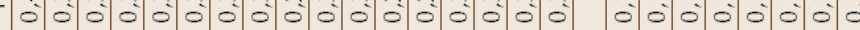

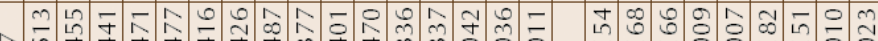

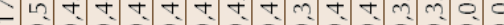

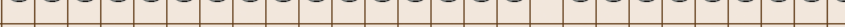

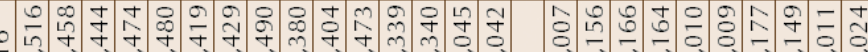

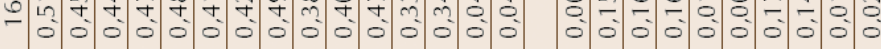

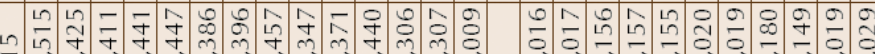

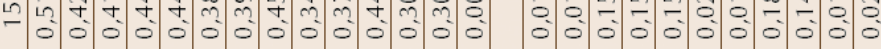

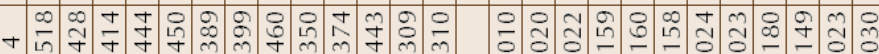
I L̂.

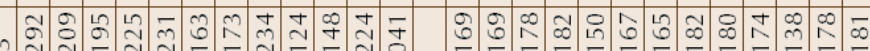

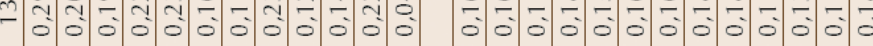

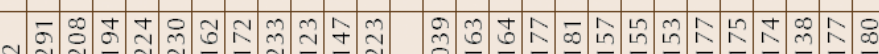

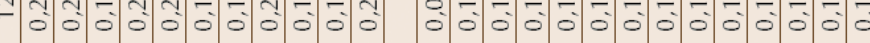

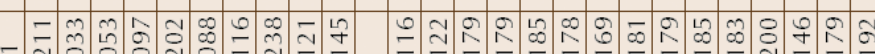

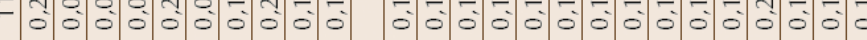

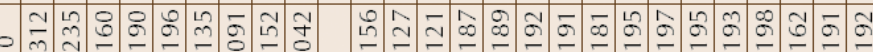
-

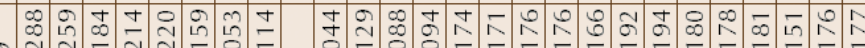

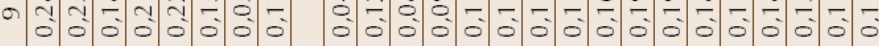

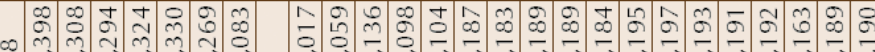

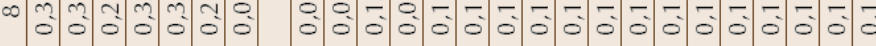

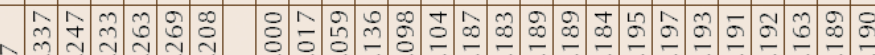

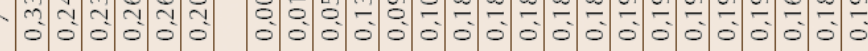

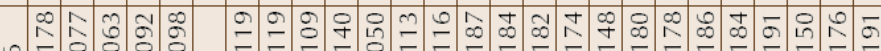
๑ Ít 는

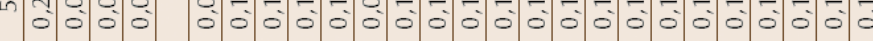

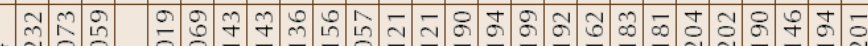
+

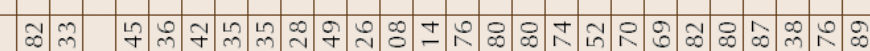

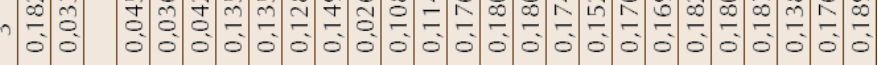
N

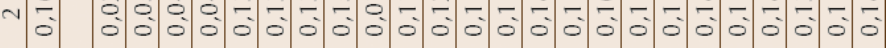

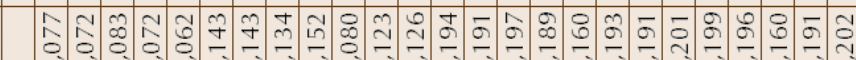

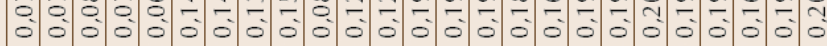

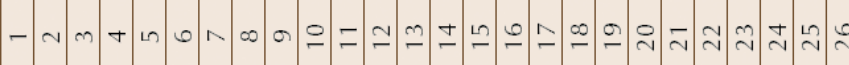




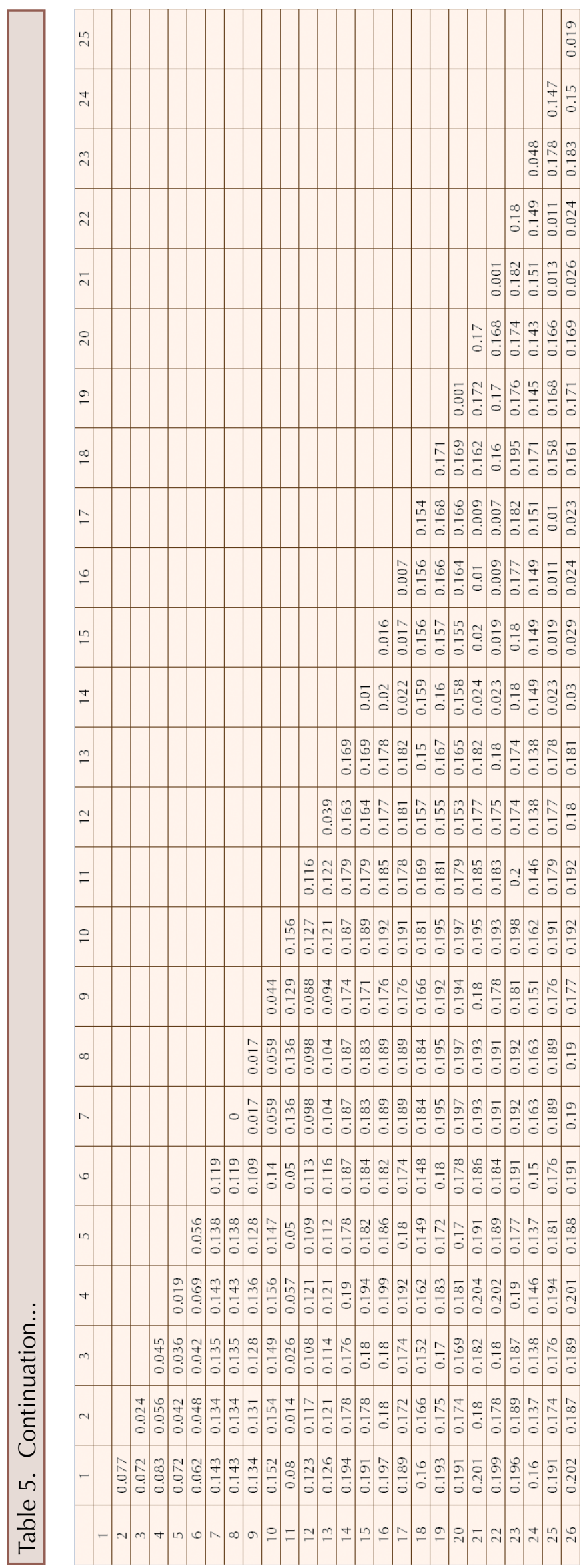

12 • REVISTA MEXICANA DE MAStOZOOLOGía Nueva época, 2014, Año 4 Núm. 1 
ovale shows a transverse process that presents a double foramen condition; petrotympanic reduced; parapterigoid-fossa square and in some cases slightly rounded; postero palatal fenestra reduced to two small holes or may disappear altogether in one side; the hamular process is attached or nearly attached along the temporal bone; interparietal bone is elongated and of approximately uniform thickness throughout its length; third molar is smaller than half the second molar; style anteromedial is absent in most specimens. In Cusco forms dorsal color Chamois to Isabelle-color with abundant black hair, with reduced lateral band without black hairs; pale olive-grey belly; ears cinnamon buff to citrine; tail bicolor drab above and olive buff below; Hind foots olive buff.

\section{Calomys miurus, Thomas 1926}

Hesperomys frida miurus, Thomas 1926

Calomys frida miurus, Cabrera 1961
Calomys sorellus, Arana-Cardo y Ascorra 1994 Calomys sorellus, Pacheco et al. 2009

Type locality.- Yanamayo, Tarma River, Junín Department, Peru.

Distribution.- Calomys miurus is distributed in the Andes of central Peru from Lima and Junín above 2,550 masl, to the Maran-Ocoña River in the north of the Arequipa Department above 3,300 masl (Figure 1).

Diagnosis.- The tail is medium-sized $(83.43 \%, \mathrm{~S}=13.94$ of $\mathrm{HB})$; the foramen ovale is reduced; the petrotympanic fissure is developed and broad; the parapterigoid pit is characteristically square; the posteropalatal fenestra is present on both sides; the hamular process is free and separated of the temporal; the interparietal bone wider at its central portion; the third molar is approximately half the size of the second; and the anteromedial style is always present (Figure 3 ). It is the most colorful of all species of Pe-

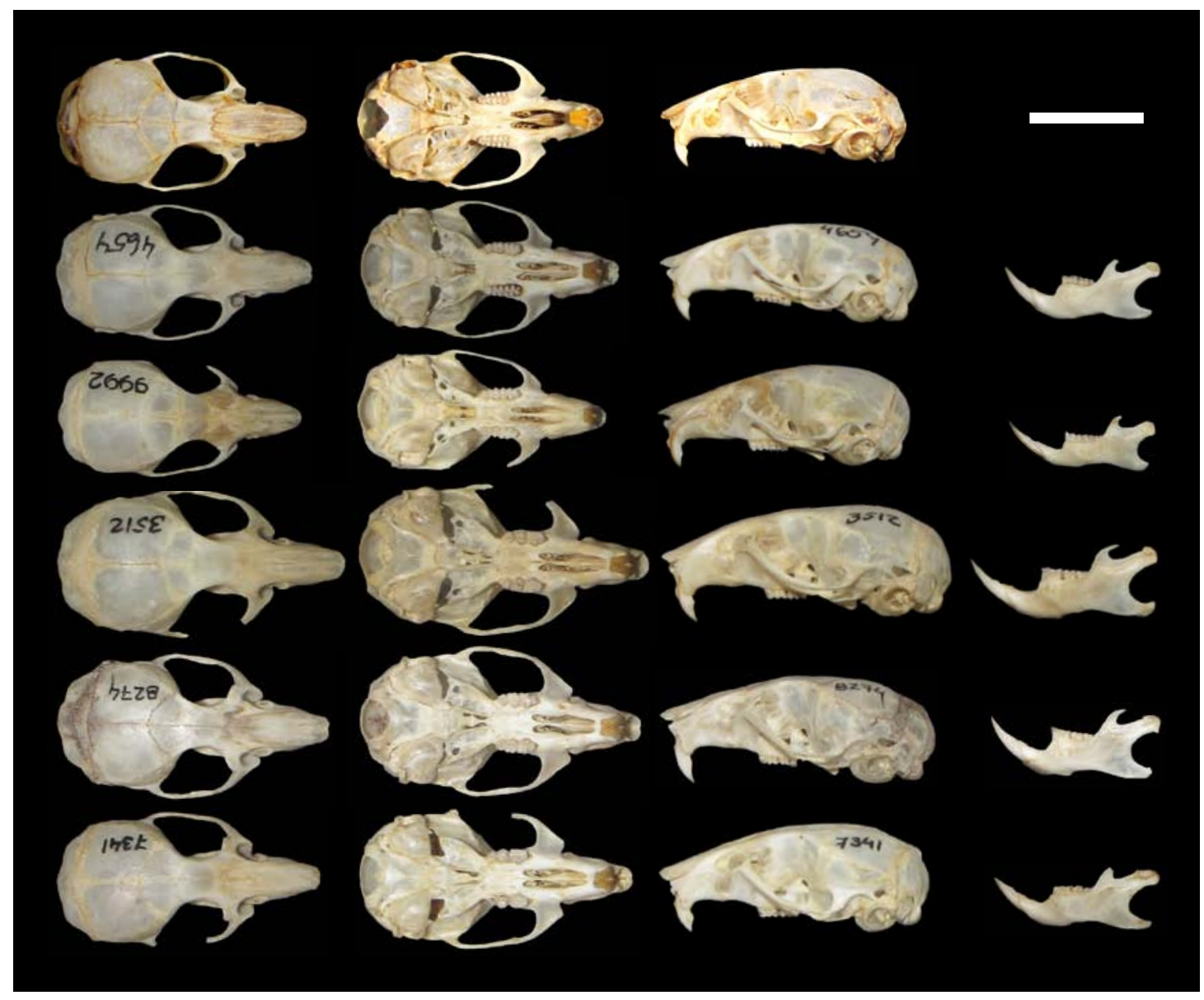

Figure 3. Comparison of Peruvian forms of Calomys sorellus COMPLEX, FROM TOP TO воттом: C. sorellus, C. miurus, C. frida from Cusco, C. frida FROM PUNO, C. achaku, AND $C$. chinchilico. 


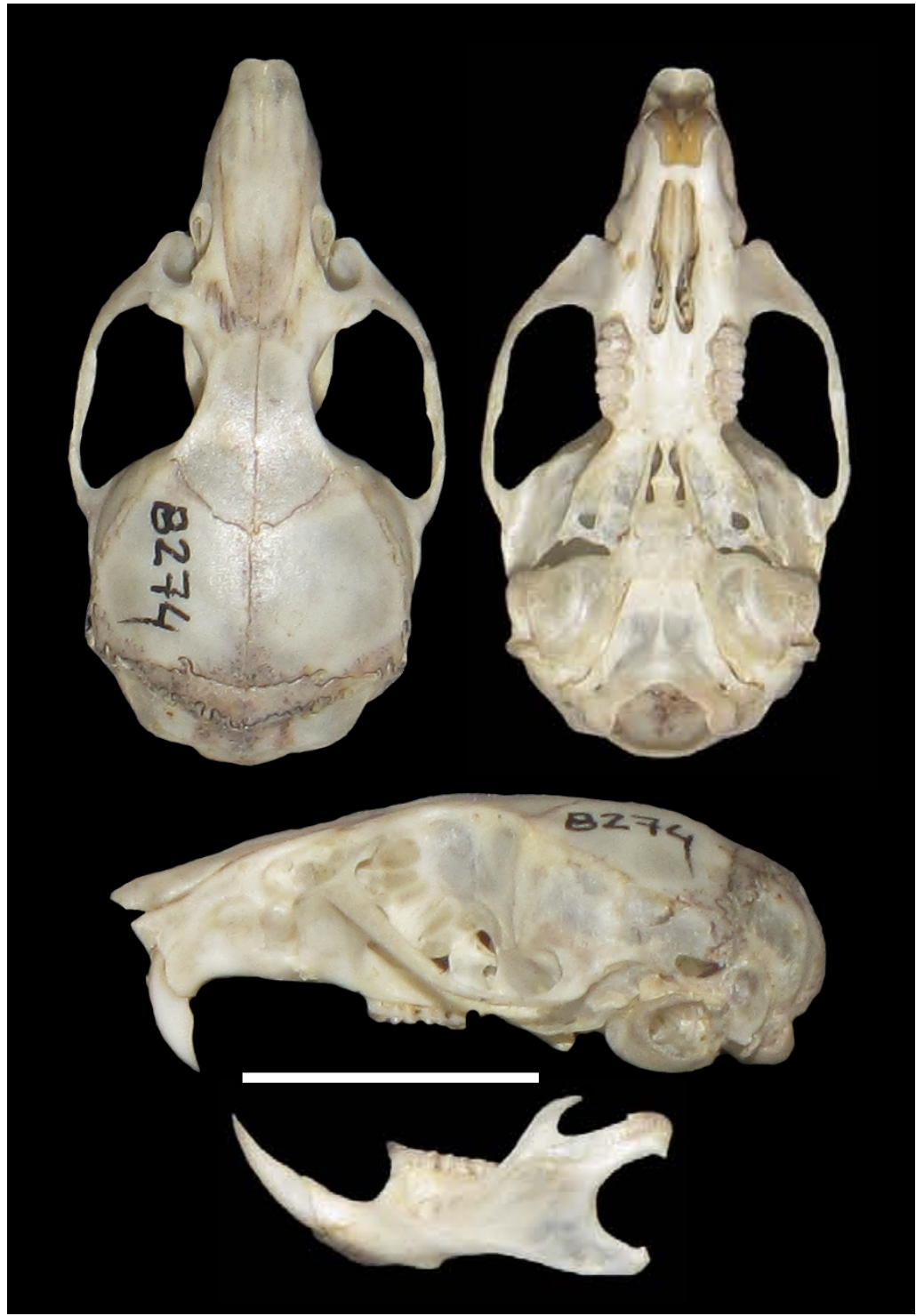

Figure 4. Dorsal, Ventral and LATERAL VIEWS OF THE SKULL OF THE HOLOTYPE OF Calomys achacu.
Type locality.- 8 miles south of Huamachuco, La Libertad Department, Peru.

Distribution.-Calomys sorellus is distributed in the Andean region northern Lima, Ancash, La Libertad Departments, above 2000 m, and Andean regions of Pasco Department.

Diagnosis. - The tail is comparatively short (about $75.82 \%, s=14.94$ of $\mathrm{HB}$ ); the foramen ovale is reduced; the petrotympanic fossa is well developed and broad; the parapterigoid fossa is lyre shaped; the posteropalatal fenestra is reduced; the hamular process is free and separated from the temporal; the interparietal bone is wider at its central portion; the third molar is reduced and covers approximately one third of the second molar; and the anteromedial style is absent (Figure 3). Dorsal color Chamois to Isabelle-color with abundant black hair, with reduced lateral band without black hairs; pale olive-grey belly; ears Isabelle-color; tail bicolor Saccardo's Umber above and whitish below; hind foots whitish.

\section{Calomys achaku, new species}

Holotype.- Adult male, skin (adult pelage), skull and partial skeleton, under collection number MUSA 8274 (Figure 4) obtained on May 2, 2010, by Horacio Zeballos under field catalogue number HZP 5233 from Linde, between Lari and Ichupampa, Colca Valley, Caylloma Province, Department of Arequipa, southern Peru (15 $38^{\circ} 32.70^{\prime \prime} S$ and $71^{\circ} 44^{\prime} 01.43^{\prime \prime} \mathrm{W}$ at 3,292 masl).

Paratypes.- MUSA 2729, La Laguna, Valle de los Volcanes, Castilla Province; 7194 El Rayo, Yanque, Caylloma Province; 8262, 8293 Linde between Lari and Ichupampa, Colca Valley, Caylloma Province; 10665 Chuquibamba, Condesuyos Province.

Distribution.- Currently known only from the highlands of the Andes of Arequipa Departmentand from the southwestern area of Puno De- 
partment in southern Peru (Figure 1).

Diagnosis. - Small size (body length: 80.40 $\mathrm{mm}, \mathrm{s}=10.03 \mathrm{~mm})$, short tail $(83.43 \%, \mathrm{~s}=7.28$ of head and body length); pelage of dorsum varying from pale gray to brown grayish with orange hairs in some specimens and white in the belly; foramen ovale large; petrotympanic fissure comparatively large; postero palatal fenestra small but always present; hamular process separated from the temporal; third molar about half the size of the second. This species is supported with a molecular phylogeny based on the Cytochrome $b$ gene, with K2P genetic distance of $2.4 \%$ and branch length (Table 5). With respect to Puno forms assigned to $C$. frida, the nodal support is high (Figure 2); with respect to nominal $C$. frida it differs by being of smaller size (external and cranial measurements) and shorter tail.

Description and comparison.-C.achaku, the sister taxon of $C$. frida (Figure 2), is distinguished by a medium tail $(83.43 \%$ of the length of $\mathrm{HB}$ as compared with $C$. frida which has the tail length equal to $92.27 \%$ of the head and body length, but is not different from the Puno forms); it also differs in size (Table 1, 2, and 3A) and by being of a pale coloration. Indeed, C. achaku is the paler form of all Peruvian Calomys; the dorsal color is cartridge buff to creamy buff with black hairs; lateral band pure Cartridge buff; whitish belly; hairs of ear Chamois; tail bicolor with Light Brownish Olive above and Cartridge buff below. The foramen ovale which does not present a transverse process is very large; the petrotympanic fissure is significantly larger than in the nominal form; the parapterygoid fossa is quadrangular to acute; the postero palatal fenestra generally is reduced to two conspicuous small holes; the hamular process is well-separated from the temporal bone; the interparietal bone is wide and rhomboidal; the third molar is approximately half the size of the second; and the anteromedial style is absent in most specimens. Other small sympatric rodents in their distribution range are: Oligoryzomys cf. andinus, Abrothrix andinus, Akodon spp., Calomys lepidus and Mus musculus, all of them with similar body sizes; Oligoryzomys andinus differs in its naked and larger tail (greater than $88 \mathrm{~mm}$ and $133 \%$ of head and body length), and comparatively large legs (greater than $22.5 \mathrm{~mm}$ ); Abrothrix andinus and Akodon have small ears and shorter tail and grayish or dark olivaceus coloration; C. lepidus is smaller and shorter tail; Mus musculus has a naked appearing tail and ears, not usual whitish ventral coloration, and its tail is similar in size to the length of head and body. The rest of rodents in the area are larger, including: Phyllotis limatus, Phyllotis magister, Auliscomys spp, Neotomys ebriosus, Abrothrix jelskii and Rattus rattus.

Measurements.- External measurements for the holotype are: total length, $156 \mathrm{~mm}$; length of tail, $69 \mathrm{~mm}$; head and body length, $87 \mathrm{~mm}$; length of hind foot, $18.9 \mathrm{~mm}$; ear from notch, $16.4 \mathrm{~mm}$; body weight $26.5 \mathrm{~g}$. The average and standard deviation of the external measurements of this type and five paratypes: total length, $151.80 \pm 17.88 \mathrm{~mm}$; length of tail, $71.40 \pm$ $6.07 \mathrm{~mm}$; head and body length, $80.40 \pm 13.85$ $\mathrm{mm}$; length of hind foot, $19.08 \pm 0.81 \mathrm{~mm}$; ear from notch, $16.56 \pm 2.90 \mathrm{~mm}$; body weight 17.70 $\pm 9.13 \mathrm{~g}$. The external measurements of $32 \mathrm{spe}-$ cimens are presented in Table 1.

Etymology.- The name Calomys, which literally translates as "beautiful mouse", is derived from the Greek "kalos" meaning beautiful and "mys" meaning mouse. The word "achaku" means mouse in the Aymara language, one of the three languages spoken in the southern Andes of Peru.

Hábitat.- This species occurs in highlands of the western slopes of southern Peru Andes in Arequipa department, in grassland communities, "tolares" and xeric vegetation assemblages composed mainly of grasses (Stipa ichu, Festuca orthophyla, Calamagorstis spp.), scrubs, called tolar (Lepidophyllum lepidophylla, Lepidophyllum quadrangulare, Bacchahris tricuneata), farmlands in Andean valleys and Polylepis forest (Figure 1, 5). 


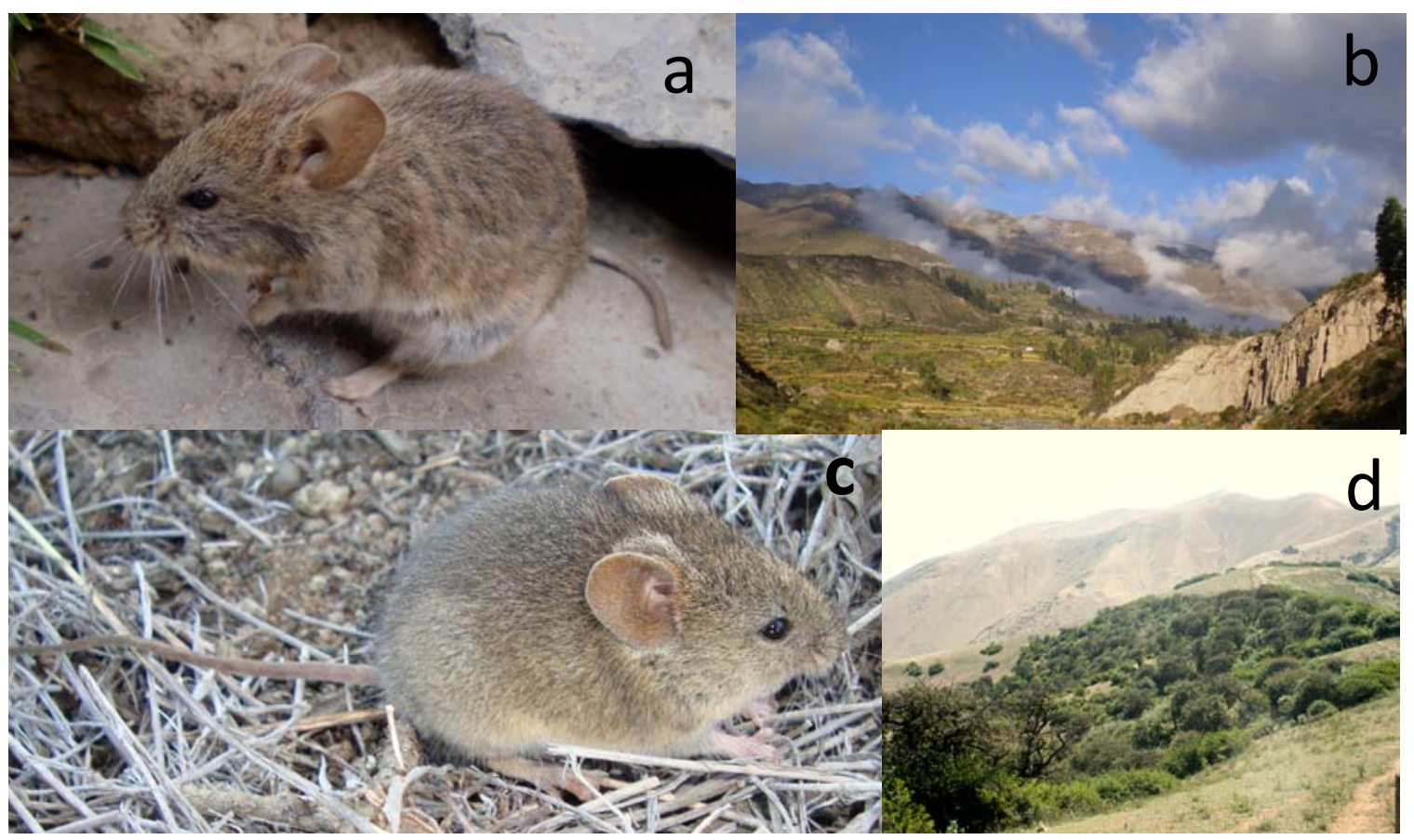

\section{Calomys chinchilico, new species}

Holotype.- MUSA 7341. Adult male, skin, skull, partial skeleton, tissues. Obtained on 1999, July 27 by Kateryn Pino under field catalogue number KPB13 (Figures 5, 6) from Cerro Lloque, Atiquipa District, Caraveli Province, Department of Arequipa, southern Peru (15 ${ }^{\circ} 46^{\prime}$ 56,65" $S$ and $74^{\circ} 21^{\prime} 13,14 " \mathrm{~W}$ at $900 \mathrm{~m}$, Figure 1).

Paratypes.- MUSA: 1568, 1569, 1570, Quebrada de la Vaca, Lomas de Taymara, Caraveli Province, Arequipa Department, Peru; 5641, Lomas de Atiquipa, Caraveli Province, Arequipa Department, Peru; 7341, 7342, Cerro Lloque, Lomas de Atiquipa, Caraveli Province, Arequipa Department, Peru.

Distribution.- Known only from the Lomas of Atiquipa and Taymara in the coastal desert of southwestern Peru (Figure 1), between 280 and $980 \mathrm{~m}$.

Etymology.- The name Calomys, which literally translates as beautiful mouse, is derived from the Greek "kalos" meaning beautiful and "mys" meaning mouse. The name "chinchilico" is a Quechua word that describes a mythological little elf-like human that lives in the galleries of gold mines. The proposed name for this species, which lives in an area known for gold deposits, makes reference to both its Andean cultural identity and its small size.

Description.- The Calomys chinchilico is a small mouse (Figure 5) and the external measurements for the holotype are: total length, $159 \mathrm{~mm}$; length of tail, $75 \mathrm{~mm}$; length of hind foot, $18.6 \mathrm{~mm}$; length of the ear, $17.3 \mathrm{~mm}$; body weight, $17 \mathrm{~g}$. The rhinarum is more developed and more inflated than in other Peruvian Calomys. The ears are ovoid with the most distal border sharp and whiskers are long and extend beyond the ears; the tragus is long and extends one-third of the length of the ear; the ears are hairy with orange hairs on the inner side, dark brown on the outside, and a patch of white hairs at the base. Guard hairs that protrude from the coat, especially in the back, less than $8 \mathrm{~mm}$ on the back.The dorsal fur varies from Deep Olive buff to Dark Olive buff and some specimens have a higher concentration of black hairs on the 
back, but they are not concentrated as distinct bands; the coat has a diffuse longitudinal band Chamois to Deep Olive buff; the sides of the head and body and the belly are whitish to Pallid Smoke grey with a base of the dark gray hairs which contrasts with the color of the sides and the back; ears tawny olive; hind foot and ventral part of the tail is pallid olive buff. The soles have six tubercles; the tarsal tubercle is very small, it is covered with small and rounded granulations in all surfaces, and it is hairy from heel to center sole. The tail is short $(86 \%$ of the length of head and body) and bicolored, yellowish-brown above and whitish below. Legs have white hairs. The first finger is a vestigial paw and has no claw and the toes of the hind legs are thin. Cranial characteristics (Figure 6) are: skull is delicate and slightly inflated in the frontal and parietal bones and has a long, thin and non-rhomboid interparietal; the foramen ovale is reduced; the petrotympanic fissure is developed and broad; the parapterygoid fenestra is rounded; the posteropalatal fenestra is small but always present; the hamular process is free and widely separated from the temporal; the interparietal is wider in its central portion; the anteromedial style is absent; the upper incisors are opisthodont without grooves; the molars are crested, more in M2 and M3 and $\mathrm{M} 1$ has a small antero lingual conule that is not noticeable in old specimens; the M2 molar has a small island of enamel.

Comparisons.- Calomys chinchilico differs from other coastal rodents of similar size by the following combination of characteristics: comparatively small size; short tail (less than $75 \mathrm{~mm}$ or $86 \%$ of head and body length); absence of hair tufts of at the tip; hairy ears are less than $16.76 \pm 1.22 \mathrm{~mm}$; typically have a post auricular patch of white hairs at the base of ears. Three small sympatric rodents, the Oligoryzomys arenalis, Phyllotis amicus, and the Mus musculus have similar body size. The Oligoryzomys arenalis differs in its naked and larger tail (greater than $88 \mathrm{~mm}$ and $133 \%$ of head and body length); and comparatively large legs (greater than $22.5 \mathrm{~mm}$ ). The Phyllotis

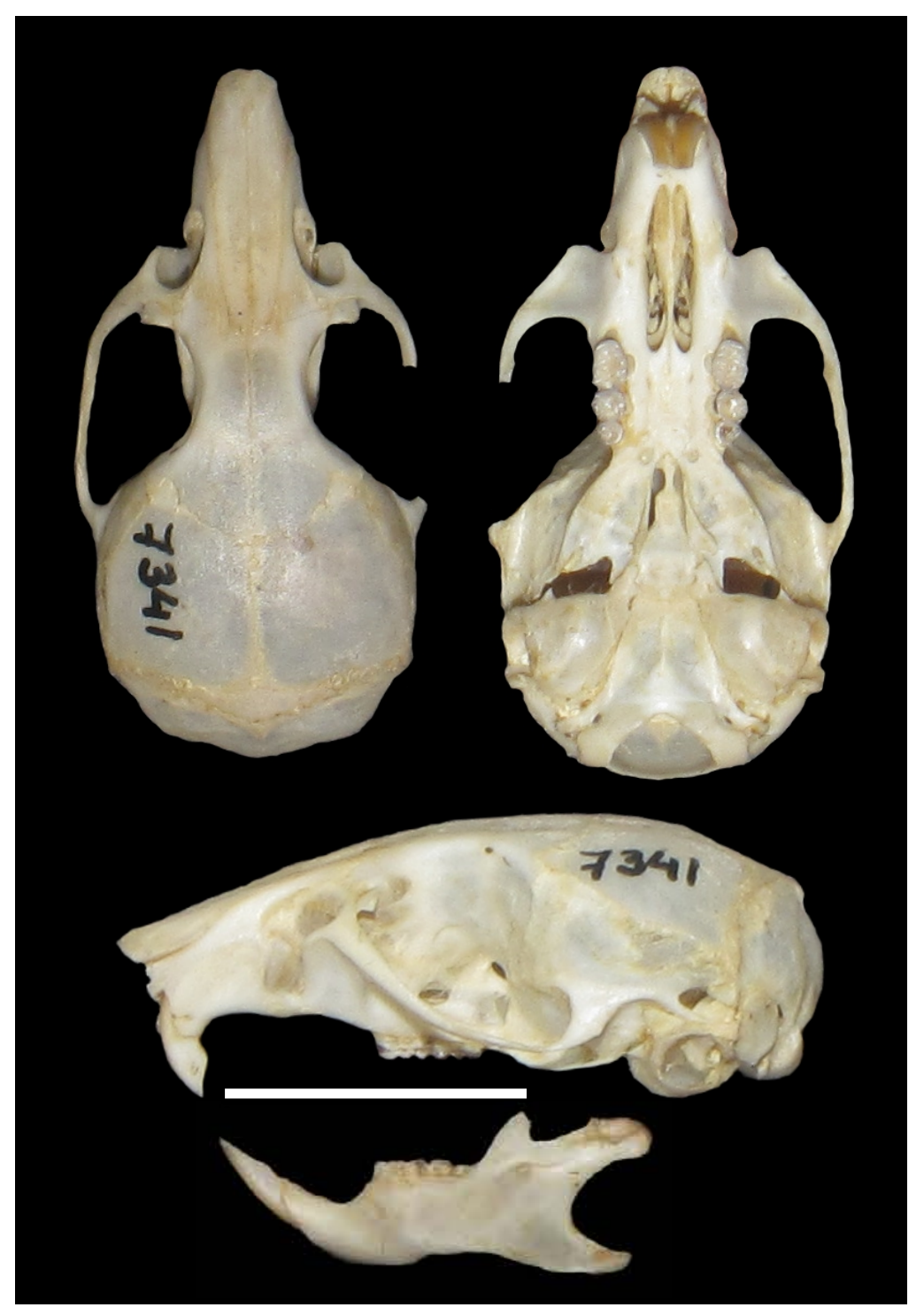

Figure 6. DORSAL, VENTRAL AND LATERAL VIEWS OF THE SKULL OF THE HOLOTYPE OF Calomys chinchilico.

amicus has a tail longer than head and body length (greater than $80 \mathrm{~mm}$ and $111.6 \%$ of the head and body length) and a tuft of hair on the end of the tail; and comparatively longer ears (larger than $19 \mathrm{~mm}$ ). Mus musculus has a naked appearing tail and ears, not usual whitish ventral coloration, and its tail is similar in size to the length of head and body. The rest of rodents in the area are larger, which include Aegialomys xantheolus, Phyllotis limatus, Phyllotis sp., and Rattus rattus.

This species differs from other Peruvian Calomys based on several characteristics 
including: fur length which is shorter (less than $8 \mathrm{~mm}$ for the dorsal hairs); its coat is yellowish brown to grayish brown, has fewer black hairs on the back, and it lacks gray shades; its ears have slightly pointed edges; the hind feet have comparatively small and delicate tubercles; the rhinarium is more developed and inflated; it has a small antero lingual conule on the first upper molar and an enamel island in the second molar (which may not be noticeable in very old individuals). They also have a different distribution range in lowlands of the Peruvian coast and separated of $C$. sorellus its closest relative by $615 \mathrm{~km}$.

The C. chinchilico is similar in body size and weight to $C$. lepidus (Table 1 ), but its tail length (more than $60 \mathrm{~mm}$ ) is longer than the tail of the C. lepidus (less than $56 \mathrm{~mm}$ ), slightly larger than that of $C$. sorellus, similar size to that of $C$. miurus, and shorter than that in $C$. frida. While the coat of $C$. chinchilico has a diffuse orange band on the sides of head and body, the fur is generally ofthe C. I. lepidus and C. I. ducillus is grayish and most specimens have abundant black hairs on the back that may look like a dark diffuse band. The ears of $C$. chinchilico are ovoid with elongated and acute edges and elongated tragus, and hairy with orange colored hairs in the inside. Postdigital tubercles in C. lepidus are developed with short and thick fingers, whereas in the C. chinchilico the sole is hairy at the center of the heel and has abundant garnulations throughout the plant of the foot, and in C. sorellus, C. achaku, C. frida and C. miurus granulations are not present in the middle part of the plant and the soles are less hairy. $C$. chinchilico differs from C. sorellus, C. achaku, C. frida and C. miurus by a more inflated rhinarium. The vibrissae of C. chinchilico extends beyond the ears, while in other species it only reaches the ears. The interparietal is long and narrow in the $C$. chinchilico and less rhomboidal in the other species, and the medial width of the frontal bone is approximately equal to or usually less than the maximum width of the rostrum. The foramen ovale differs from that in the $C$. sorellus and is simple and less developed than in the $C$. frida and C. achaku. The petrotympanic fissure is comparatively wider in the $C$. chinchilico when compared to that in the $C$. achaku and $C$. frida, and the posteropalatal fenestra is conspicuous, unlike that in C. miurus, C. achaku, C. frida and $C$. sorellus in which they are small. The wide separation of the hamular process from the temporal bone and the greater width of the middle of the interparietal in the C. chinchilico distinguish it from $C$. frida.

Habitat.- This species inhabits only the Taymara and Atiquipa lomas, an area where tree and shrub formations obtain moisture from mist condensation (Figure 5). C. chinchilico is more abundant in shrub associations of Grindelia glutinosa, Mimosa albida, Croton nodiflora and Lippia alnifolius and in isolated patches of Nicotiana paniculata. It is rarely found in areas with dense vegetation of shrubs of Duranta armata, Citarexilum flexuosum, arboreal vegetation of Caesalpinia spinosa, or the Atiquipa endemic tree Myrciantes ferreyrae. Its greater abundance in small bushes, especially G. glutinosa, suggests that this new species has a preference for open land dotted with tall and low shrubs, such as is found in the high Andes.

\section{DISCUSSION}

Molecular evidence suggests a close phylogenetic relationship between $C$. sorellus, $C$. musculinus and $C$. lepidus (Salazar-Bravo et al., 2001; Almeida et al., 2007; Haag et al., 2007; Bonvicino et al., 2010). Collectively, they constitute a sister clade relative to other species (C. hummelincki) in the eastern lowlands of the Andes and the northern Andes of South America. We suggest that the Andean Calomys species exhibit remarkable morphological, molecular and karyotypic differences underlying the recognition of full species status to various forms previously included in C. sorellus and $C$. lepidus (Espinoza et al., 1997; Salazar-Bravo et al., 2001; Mattevi et al., 2005; Bonvicino et al., 2010). In addition, their remarkably allopatric distributions may have fostered the evolution of these distinct species. 
At the molecular level we found that species of the eastern lowlands are well defined and supported (Salazar-Bravo et al., 2001; Almeida et al., 2007; Haag et al., 2007, Bonvicino et al. 2010). In those works the genetic distance (K2P) varied from $1.3 \%$ to $4.1 \%$ in closely related species, such as $C$. callosus-C. fecundus (called $C$. boliviae by Bonvicino et al. 2010 and Haag et al. 2007). Our results (Table 5 ) described lower values to genetic distance in closed forms of lowlands from $1.0 \%$ between C. fecundus and $C$. venustus; $1.6 \%$ between $C$. callosus and C. fecundus; $1.9 \%$ in "innominate" with $C$. fecundus or C. callosus; or C. venustus- $C$. fecundus. In contrast, the genetic distance in the Andean forms range from 2.4 $\%$ and $4.5 \%$ in closely species such as $C$. frida, with $C$. achaku or $C$. miurus respectively; to values exceeding $6.0 \%$ for more distantly related species such as $C$. chinchilico and $C$. sorellus. Comparatively all Andean species of Calomys are highly supported by both bootstrap and posterior probability estimates (Figure 2), revealing a wide diversity comparable to that in the lowlands of the eastern of Andes. However, more samples and studies at a higher resolution are needed to more precisely describe the status of $C$. lepidus and $C$. frida. In particular, the $C$. frida forms from Puno are assigned to this species only tentatively (due to lack of molecular data) as they doshow remarkable morphological differences that suggests a specific level differentiation.

C. sorellus is a complex of at least five species (Figure 2), all of which are endemic from Peru: C. sorellus from northern Lima, Ancash Trujillo, northern most Junin and Andean Pasco Departments; C. miurus from Lima, Huancayo, Junin, Ayacucho and Huancavelica and northern most Arequipa Departments; C. frida with two forms: the nominal form from Abancay and Cusco Departments, and Puno's forms; two new species described in this paper, $C$. chinchilico, which inhabits the coastal lomas of Taymara and Atiquipa in the southwestern region of Arequipa Department, and C. achaku from the western slopes of southern Andes of Arequipa and Moquegua Departments. The latter new species is the only non-Andean form of this radiation and its presence on the coast is explained by the recurrent phenomena associated with climate dynamics of this part of America (Betancourt et al., 2000; Latorre et al., 2007).

Our preliminary results from $C$. lepidus samples and the data clearly show that $C$. lepidus is a species complex which needs to be further explored by incorporating samples from Bolivia and Argentina. All Andean species and $C$. musculinus are monophyletic, and the basal position of $C$. musculinus is consistent with its geographical distribution. Molecular studies show that the genus Calomys is one of the most diverse genera of the open lands of South America, and recently this observation has been documented also for the lowlands (Almeida et al., 2007; Bonvicino et al., 2010). Our research has recognized that Calomys in the high Andes is more diverse than previously thought and that evolutionary processes leading to speciation have been highly significant in the Andes.

\section{ACKNOWLEDGEMENTS}

The principal author, Horacio Zeballos, extends his gratitude and recognition to Pontificia Universidad Catolica de Chile, which allowed himto continue his doctoral studies, and in particular, the DIPUC that supported him asa Research Assistant and Instructor. All the authors acknowledge and extend their appreciation to The Center for Advanced Studies in Ecology and Biodiversity (caseb, 1501-001 fondap-fondecyt) and the Millennium Scientific Initiative (P05002) and the Basal Funding Grant conicyt PFB23 for funding much of the field expenses, as well as the NGO Centro de Investigación para la Promoción de los Pueblos (Bienestar) and the Natural History Museum of the Universidad Nacional de San Agustin de Arequipa. The authors also acknowledge The National Institute of Natural Resources, Ministry of Agriculture of Peru for the research permits the following for access to their research collections: Julieta Vargas of the Colección Boliviana de Fau- 
na of the Universidad Nacional Mayor de San Andrés; Victor Pacheco of the Natural History Museum of the Universidad Nacional Mayor de San Marcos; and Evaristo Lopez of the Museum of Natural History at the Universidad Nacional de San Agustin de Arequipa. The authors also acknowledge the valuable help in the field provided by Roberto L. Barrionuevo, Roberto C. Gutierrez, Fernando Zeballos, and Kenny Caballero. Bjorkland R. A review of the previous version of the manuscript. $G$. Ceballos was supported by the DGAPA of the National Autonomous University of Mexico.

\section{LITERATURE CITED}

Almeida, F.C., Bonvicino, C.R.P. Cordeiro-Estrela. 2007. Phylogeny and temporal diversification of Calomys (Rodentia, Sigmodontinae): Implications for the biogeography of an endemic genus of the open/dry biomes of South America. Molecular Phylogenetics and Evolution, 42: 449-466.

Akaike, H. 1974. A new look at the statistical model identification.IEEE Transactions on Automatic Control, 19:716-723.

Anderson, S. 1997. Mammals of Bolivia, taxonomy and distribution. Bulletin of the American Museum of Natural History, 231:1-651.

Baskin, J.A. 1978. Bensonomys, Calomys and the origin of the phyllotine group of Neotropical cricetines (Rodentia: Cricetidae). Journal of Mammalogy, 59:125-135.

Betancourt, J.L., C. Latorre, J.A. Rech, J. Quade, and K.A. Rylander. 2000. A 22,000-yr record of monsoonal precipitation from northern Chile's Atacama Desert. Science, 289:1542-1546.

Bonvicino, C.R. and F.C. Almeida. 2000. Karyotype, morphology and taxonomic status of Calomys expulsus (Rodentia: Sigmodontinae). Mammalia, 64(3):339-351.

Bonvicino, C.R., J.A. Oliveira and R. Gentile. 2010. A new species of Calomys (Rodentia: Sigmodontinae) from Eastern Brasil. Zootaxa, 2336:19-25.
Cabrera, A. 1961. Catálogo de los mamíferos de América del Sur, Parte II. Revista del Museo Argentino de Ciencias Naturales Bernardino Rivadavia, Ciencias Biológicas, 4:309732.

Carleton, M.D. and G.G. Musser. 1989. Systematic Studies of Oryzomyine Rodents (Muridae: Sigmodontinae): synopsis of Microryzomys. Bulletin of the American Museum of Natural History, 191:1-83.

Catzeflis, F.M., J.P. Aguilar y J.J. Jaeger. 1992. Muroid rodents: Phylogeny and evolution. Trends in Ecology and Evolution, 7(4):122-126

Corti, M., M.S. Merani and G. de Villafañe. 1987. Multivariate morphometrics of Vesper mice (Calomys): preliminary assessment of species, population and starin divergence. $Z$. Saugetierkunde, 52:236-242.

Edwards, S.V., P. Arctander and A.C. Wilson. 1991. Mitochondrial resolution of a deep branch in the genealogical tree for perching birds. Proceedings of the Royal Society of London, Ser. b, 243: 99-107.

Ellerman, J.R. 1941. The families and genera of living rodents. London British Museum of Natural History, 1-690.

Espinoza, M.B., A. Lasserre, M. Plantanida and A.D. Vitullo. 1997. Cytogenetics of vesper mice, Calomys (Sigmodontinae): a new karyotype from Puna region and its implication for chromosomal phylogeny. CMLS Cellular and Molecular Life Sciences, 53:583-586.

Felsenstein, J. 1981. Evolutionary trees from DNA sequences: A maximum likelihood approach. Journal of Molecular Evolution, 17:368-376.

Felsenstein, J. 1985. Confidence limits on phylogenies: a approach using the bootstrap. Evolution, 39:783-791.

Gonzalez-ltigg, R.E., J.L. Patton and C.N. Gardenal. 2007. Analysis of Cytochrome-b nucleotide diversity confirms a recent range expansion in Calomys musculinus (Rodentia, Muridae). Journal of Mammalogy, 88(3):777-783.

Haag, T., V.C. Muschner, L.B. Freitas, L. Flamarion, B. Oliveira, A.R. Langguth and M.S. Mattevi. 2007. Phylogenetic relationships among species of the genus Calomys with emphasis on South American lowland taxa. Journal of Mammalogy, 88(3):769-776.
Hershkovitz, P. 1962. Evolution of Neotropical cricetine rodents (Muridae), with special reference to the Phyllotine group. Fieldiana: Zoology, 46:1-524.

Hall, T.A. 1999. BioEdit: a user friendly biological sequence alignment editor and analysis program for Windows 95/98/NT. Nucleic Acids Symp. Ser.: 41: 95-98.

Huelsenbeck, J. P. and F. Ronquist. 2001. MrBayes: Bayesian inference of Phylogeny. Bioinformatics, 17:754-755.

Kimura M. 1980. A simple method for estimating evolutionary rate of base substitutions through comparative studies of nucleotide sequences. Journal of Molecular Evolution, 16:111-120.

Kocher, T.D., T.K. Thomas, S.V. Edwards, S. Paabo, F.X. Villablanca and A.C. Wilson. 1989. Dynamics of mitochondrial DNA evolution in mammals: amplification and sequencing with conserved primers. Proccedings of National Academy of Sciences, 86:6196-6200.

Laird, P.W., A. Zijderveld, K. Linders, M.A. Rudnicki, R. Jaenisch, and A. Berns. 1991. Simplified mammalian DNA procedure. Nucleic Acid Research, 19: 4293.

Latorre, C., P.I. Moreno, G. Vargas, A. Maldonado, R. Villa-Martínez, J. Armesto, C. Villagrán, M. Pino, L. Núñez and M. Grosjean. 2007. Late Quaternary environments and palaeoclimate, Pp. 309-328 in: The Geology of Chile. (Gibbons, W. y T. Moreno, eds.). London Geological Society Press, London.

Longmire, J.L., A.K. Lewis, N.C. Brown, J.M. Buckingham, L.C. Clarck, M.D. Jones, L.J. Meincke, J. Meyne, R.L. Ratleef, F.A. Ray, R.P. Wagner and R.K. Moyzis. 1988. Isolation and molecular characterization of a highly polymorphic centromeric tandem repeat in the family Falconidae. Genomics, 2:14-24.

Massoia, E., A. Fornes, R.L. Weinberg y T.G. de Fronza. 1968. Nuevos aportes al conocimiento de las especies bonaerenses del género $\mathrm{Ca}$ lomys (Rodentia-Cricetidae). Revista de Investigaciones Agropecuarias, INTA, Buenos Aires, ser. 1, Biología y Producción Animal, 5(4):63-92.

Mattevi, M.S., T. Haag, L.F.B. Oliveira and A.R. Langgugh. 2005. Chromosome characterization of Brazilian 
species of Calomys Waterhouse, 1837 from Amazon, Cerrado and Pampa domains (Rodentia, Sigmodontinae). Arquivos de Museu Nacional, 63(1):175-181.

Musser, G.G. andM.D. Carleton. 2005. Superfamily Muroidea. Mammal species of the world: a taxonomic and geographic reference. Baltimore MD: Johns Hopkins University Press.

Olds, N. 1988. A Revision of the Genus Calomys (Rodentia: Muridae). Doctoral Thesis, City University of New York.

Pacheco, V. 2002. Mamíferos del Perú, Pp. 503-550, in: Diversidad y Conservación de los Mamíferos Neotropicales (G. Ceballos y J. Simonetti, eds.). CONABIO-UNAM. México, D.F. CONABIO-UNAM. México, D.F.

Pearson, O.P. 1951. Mammals in the Highlands of Southern Peru. Bull. Mus. Comp. Zool. Harvard. (106):117174.

Pearson, O.P. y J.L. Patton. 1976. Relationships among South American phyllotine rodents based on chromosome analysis. Journal of Mammalogy, 57: 339-350.

Posada, D. y K.A. Crandall. 1998. Modeltest: testing the model of DNA substitution. Bioinformatics, 14:263285.

Reig, O.A. 1986. Diversity pattern and differentiation of High Andean rodents. Pp. 404-439, in: High altitude tropical biogeography (F. Vuillemier and M. Monasterio, eds.). New York: Oxford University Press.

Ridgway, R. 1912. Color Standards and color nomenclature. A. Hoen and Company, Baltimore.

Ronquist, F. and J.P. Huelsenbeck. 2005. MrBayes v3.1. Bayesian Analysis Phylogeny. Florida: School for computational science, University of California.

Rozas, J., J. C. Sánchez-del Barrio, X. Messeguer and R. Rozas. 2003. DnaSP, DNA polymorphism analysis by the coalescence and other methods. Bioinformatics, 19: 24962497.

Saiki, R.K., D.H.S., Gelfand, S.J. Stoffel, R. Scharf, G.T. Higuchi Horn, K.B. Mullis, y H.A. Erlich. 1988. Primer-directed enzymatic amplification of DNA with a thermostable DNA polymerase. Science, 239: 487-491.

Salazar-Bravo, J., J.W. Dragoo, D.S. Tinnin and T.L. Yates. 2001. Phylogeny and evolution of the Neotropical rodent genus Calomys: Inferences from mitochondrial DNA sequence data. Molecular Phylogenetics and Evolution, 20:173-184.

Steppan, S.J. 1995. Revision of the Tribe Phyllotini (Rodentia: Sigmodontinae), with a phylogenetic hypothesis for the Sigmodontinae.Fieldiana (Zool.), 80: 1-112.

Swofford, D.L. 2002 PAUP: Phylogenetic relationships using parsimony. Illinois Natural History Survey, Champaign.
Tamura K., D. Peterson, N. Peterson, G. Stecher, M. Nei and S. Kumar. 2011. MEGA5: Molecular Evolutionary Genetics Analysis using Maximum Likelihood, Evolutionary Distance, and Maximum Parsimony Methods. Molecular Biology and Evolution (In Press).

Thompson, J.D., T.J. Gibson, F. Plewniak, F. Jeanmougin andD.G. Higgins. 1997. The Clustal $X$ windows interface: flexible strategies for multiple sequence alignment aided by quality analysis tools. Nucleic Acids Research, 25: 4876-4882.

Voss, R.S. 1988. Systematics and ecology of Ichthyomyine rodents (Muroidea): Patterns of morphological evolution in a small adaptive radiation. Bulletin of the American Museum of Natural History, 188:259-493.

Williams, D.F., and M.A. Mares. 1978. A new genus and species of phyllotine rodent (Mammalia: Muridae) from northwestern Argentina. Annals Carnegie Museum, 47:192-221.

Wilson, D.E. y D.A. Reeder (eds). 2005. Mammal Species of the World. A Taxonomic and Geographic Reference, 3rd edition. Johns Hopkins University Press, Baltimore.

Xia, X., Z. Xie, M. Salemi, C. Lu, y W. Yong. 2003. An index of substitution saturation and its application. Molecular Phylogenetics and Evolution, 26, $1-7$. 
Annex 1. Analyzed specimens (Museo de Historia Natural de la Universidad San Agustín, MA; Colección Científica asociada al Museo de Historia Natural de la Universidad Nacional de San Agustín de Arequipa, MUSA; Colección Boliviana de Fauna, CBF; Museo de Historia Natural de la Universidad Nacional Mayor de San Marcos, MUSM).

Calomys frida. Perú.- Apurímac: Pachachaca, Abancay (MUSA 11267); Carboncallana, Abancay (MUSM 15138, 15139). Ayacucho: Camino a Acocro, Huamanga (MUSA 10730, 10739, 10740); Ichupampa, Huamanga (MUSA 10744, 10745, 10752); Pausa, Paúcar del Sara Sara (mUSA 10753); Alrededores de Putaja, Cochas (mUSA 10746, 10748). Cusco: Acjanaco, Paucartambo (mUSA 4006, 4011, 4072); 5 km N. Huancarani (mUSM 1821); Qda. Quellouno, Calca (mUSA 5642, 5643, 5644, 5645); Matarococha, Yanaoca (MUSA 8734); Yayapara, Yanaoca (MUSA 9991); Lag. Pomacanchi, Acomayo (mUSA 9992, 9993). Puno: Pasincha, Azángaro (mUSA 1343); Hda Checayani, Azángaro (mUSM 2317); Lag. Ticani Moho (MUSA 3500, 3505); Cerro Saiguane, Río Ucumarini (MUSA 3512, 3515); 4.5 km NE. San Anton (Musm 2312, 2313). Calomys achaku. Perú.-Arequipa: Achoma (mUSM 2314, 2315, 2316); Tuctumpaya (mUSA 11073, 11248, 11256, 11261, 11264, 11266, 11268, 11271, 11328); La Laguna, Valle de los Volcanes (muSA 2729); Huanacaure, Andahua (mUSA 2757, 2758, 2759, 2760); Hda. Jjocca, Pillone (mUSA 75); Chaco, Río Colca (mUSA 272); Chivay, Río Colca (mUSA 280); El Rayo, Yanque (mUSA 7194); Linde, Ichupampa, Río Colca (mUSA 8245, 8259, 8262, 8264, 8274, 8293); Chuquibamba (MUSA 10428, 10665). Moquegua: Mariscal Nieto, Torata, Mina Cuajone, Rio Torata (musm 14999, 15018, 15026).Tacna: Anexo Tacjata, Comunidad de Vilacota, Susapaya, Tarata (mUSA 12309). Calomys miurus. Perú.-Arequipa: Ayacucho: Cochas (MUSA 7688); Patibamba (MUSA 7680, 5943, 5944, 5946); Qda. Campana (mUSA 5942, 7697, 7698). Huancavelica: San Pedro de Coris (mUSA 12013); sin localidad (musm 2639, 5948, 5949, 5951, 5954, 5959, 5960, 5961, 5962, 5964, 5965, 5966, 5967, 5968, 5969, 5973). Huancavelica: Acobamba (mUSM 16136, 16138). Huánuco: Acococha, Quio-Caina (MUSA 10675). Junín: entre Jauja y Acolla (MUSA 4633, 4634, 4635, 4636, 4637, 4638, 4639, 4640, 4641, 4643, 4647, 4648, 4649, 4650, 4651, 4652, 4653, 4654, 4658, 4659, 4660, 4662, 4663, 4664,4665, 4666, 4667, 4668, 4669, 4670, 4671, 4672, 4673, 4674, 4675, 4676); SAIS Tupac Amaru, Jauja (mUSm 8439, 8441, 8443, 8444, 8446, 8449); Canchayllo (MUSA 5295, 5323, 5339, 5340, 5341, 8697, 8701); Ondores, Lago Junín (mUSA 4920, 4945). Lima: Bosque Karka, Vilca (mUSA 5355, 5357); Vitis, Yauyos (mUSA 8666, 8667); Atavillos Alto; Huaral (mUSA 11943, 11944); Pacomanta, Huarochiri (mUSm 573, 574); 1 km N. San Pedro de Casta, Huarochirí (musm 575); Alto Río Sta. Eulalia (musm 576, 577); Calomys sorellus. Perú.- Ancash: Tinco, 14,5 km E de Huaraz (musa 4799). Huánuco: Acococha, Ambo (muSa 10675). Lima: Oyon (musm 10751, 10753, 10754, 10755). Pasco: Yacupianan, Huariaca (mUSA 12137); Ancatana, Pampa Hermosa, Huariaca (muSA 13128); Tingo/Hatun Putahua, Ticlacayan (mUSA 12147, 12152, 12153, 12154, 12158, 12159). Calomys chinchilico. Perú.- Arequipa: Cerro Lloque, Lomas de Atiquipa (mUSA 7340, 7341, 7342, 7358, 7359, 7360, 7365, 7366, 7367); Lomas de Atiquipa (mUSA 4093, 4094, 5641, 10958, 11071, 11072); Lomas de Taymara (mUSA 1449, 1568, 1569, 1570). Calomys lepidus. Bolivia.-La Paz: Reserva Nacional de Fauna Ulla Ulla, a $11 \mathrm{~km}$ de la Cabaña IBTA (CBF 6412, 6435, 6436). Oruro: 1,5-2 km SO Sajama (CBF 2201, 2205, 2207), Parque Nacional Sajama (CBF 2208); E del Lago Poopo, 4 km by rd N Huancane (CBF 6038); Abaroa, desvío km 181 S Oruro (CBF 6041). Cochabamba: 13Km N de Colomi, Chaparé (CBF 3616, 3675). Peru.- Ancash: Huaraz, Cordillera Negra (mUSM 11621, 11622, 11624, 11626, 11627, 11627). Arequipa: San Juan de Tarucani mUSA 7126, 7137); Lag. Orcococha, Cármen de Chaclaya (mUSA 8314, 8330), Pampa Cañahuas (mUSA 7127, 7129, 7130); Quenco, Callalli (MUSA 79); Imata (mUSA 74), Mauca Arequipa, Imata (mUSA 1150); Tapay, río Colca (MUSA 12015, 12016); Chajhui, Hda. Quilcapata (mUSA 83, 84); Chalhuanca, Yanque (MUSA 6980, 8622); Ayacucho: Camino a Acocro, Huamanga (MUSA 10741, 10742, 10743); Ichupampa, Huamanga (mUSA 10749, 10751); Cusco: Pallpata, Espinar (mUSA 8116). Huancavelica: Chacapampa San Pedro de Coris (mUSA 12013). Huánuco: Yanapacho, Ambo (mUSA 10729). Junín: Canchayllo, Jauja (MUSA 5311). Pasco: Huayllay (MUSA 9994, 10427); Ticlayán, Tingo/ Hatun Putahua (MUSA 12142). Puno: Caccachara (MUSA 4386); Cieneguilla, Cabana (mUSA 8720); $4.5 \mathrm{~km}$ NE. (by rd) San Anton (musm 2309, 2310); Ilave, ca Puno (musm 2311). Tacna: Laguna Blanca, Palca (musa 12454). Calomys musculinus. Bolivia.- Chuquisaca: 2 km N Tarabuco, Yamparaes, (CBF 1083); Tarija: 1 km E Tucumillas, Méndez (CBF 2089, 2093); Tucumillas, San Lorenzo (CBF 2246), Tapecuá, Entre Ríos (CBF 2306). 
Annex 2. List of species, cytochrome b gene sequences used for phylogenetic reconstruction and, localities records. We used sequences obtained from GeneBank and samples obtained by our field collection.

Calomys venustus: AY033176 (Santiago del Estero, Argentina); AY033174 (Córdova, Argentina); Calomys fecundus: AY033172 (Porvenir, Tarija, Bolivia): AY033173 (Tucumán, Argentina); Calomys "innominado": AY033156 (Chumano, Beni, Bolivia); AY033157 (La República, Beni, Bolivia); Calomys callosus:

AY033185 (Cerro Cora, Paraguay); AY033187 (Monte Palma, Paraguay); Calomys laucha: AY033189

(Estancia Bolívar, Tarija, Bolivia); AY033190 (Boquerón Filadelfia, Paraguay); Calomys tener: AY041193

(Brasil); AF385597 (Brasil); Calomys hummelincki: AF385598 (Isiro, Falcón, Venezuela); Calomys frida:

U03543 (Putina, Puno, Perú); Calomys argurus: AF159294 (Iscayachi, Bolivia) Calomys lepidus ducillus:

AF159294 (Ulla Ulla, La Paz, Bolivia); U03544 (Putina, Puno, Perú); Calomys musculinus: NK23706

(Tarija, Bolivia); AF385603 (Catamarca, Argentina); Eligmodontia hirtipes: AF 159289 (La Paz, Bolivia);

Andalgalomys pearsoni: AF 159285 (Santa Cruz, Bolivia); Loxodontomys micropus: AF 108690 (Rio Negro, Argentina). Additional sequences of: Calomys achaku: (Viraco, Arequipa, Perú); (Chuquibamba, Arequipa, Perú); Calomus miurus: (Jauja, Perú); (Ondores, Junín, Perú); Calomys sorellus: (Tinco, Ancash, Perú); Calomys chinchilico: (Atiquipa, Perú); Calomys lepidus lepidus: Chiguata, Arequipa, Perú; Auliscomys sublimis (Tocra, Arequipa, Perú). 